\title{
Sudski postupci protiv katoličkoga tiska u komunističkoj Hrvatskoj 1960-ih i 1970-ih
}

\author{
ANTO MIKIĆ \\ Hrvatsko katoličko sveučilište, Odjel za komunikologiju \\ Zagreb, Hrvatska \\ anto.mikic@unicath.hr
}

\begin{abstract}
U radu su prikazani sudski postupci protiv katoličkih novina Mali koncil, Glas Koncila i Glasnik sv. Antuna Padovanskoga (poslije Veritas) te njihovih urednika i autora Franje Kuharića, Živka Kustića i Ivona Čuka šezdesetih i sedamdesetih godina XX. stoljeća. Na temelju izvornoga arhivskoga gradiva i relevantne literature rekonstruirano je sedam različitih sudskih postupaka, od prekršajnih preko postupaka zabrane raspačavanja i zapljene pojedinih članaka (araka na kojima su tiskani) ili brojeva spomenutih listova, pa sve do dva kaznena postupka - protiv Ivona Ćuka i Živka Kustića - kojima su tadašnje vlasti nastojale ograničiti pisanje katoličkoga tiska, a posredno i djelovanje Katoličke crkve u društvu. Služeći se različitim znanstvenim metodama - od metode deskripcije i komparacije arhivskoga gradiva, preko analize tadašnjih zakonskih propisa i sudskih spisa te sadržaja službenih kontakata tadašnjih državnih i crkvenih predstavnika i sve do analize pojedinih objavljenih članaka u tadašnjem katoličkom tisku - autor ovim radom dodatno rasvjetljuje ne samo pravne aspekte tih postupaka nego i njihovu političku pozadinu i motivaciju.
\end{abstract}

Ključne riječi: katolički tisak; komunizam; Glas Koncila; Mali koncil; Veritas; Ivon Ćuk; Živko Kustić; Franjo Kuharić

\section{Uvod}

Prva polovina šezdesetih godina XX. stoljeća u životu Katoličke crkve u tadašnjoj Hrvatskoj i Jugoslaviji bila je obilježena obnovom katoličkoga tiska, koji je u vrijeme Drugoga svjetskog rata zbog ratnih i gospodarskih prilika bio znatno oslabljen, a prestankom rata 1945. gotovo potpuno ukinut jer je nova komunistička vlast sustavno - uskratom papira, konfiskacijom tiskarskih strojeva i zatvaranjem tiskara - onemogućila djelovanje katoličkih izdavača. Primjerice, makarski franjevci pokreću liturgijsko-pastoralni list Služba Božja 
(1960.), franjevci konventualci u Zagrebu mjesečnik Glasnik sv. Antuna Padovanskoga (1962., od 1968. mijenja naziv u Veritas), splitski franjevci list Marija (1963.), isusovci u Zagrebu obnavljaju izdavanje časopisa Glasnik Srca Isusova i Marijina (1963.), a ujesen 1963. zagrebački nadbiskup Franjo Šeper osniva i najvǎniji katolički list - (dvo)tjednik Glas Koncila, kojemu će prethoditi 11 brojeva biltena Glas s Koncila od listopada do prosinca 1962., u vrijeme prve sjednice Drugoga vatikanskoga koncila. ${ }^{1}$

Tu su pojavu, među ostalim, omogućila i dva procesa koja su obilježila to razdoblje u povijesti tadašnje Hrvatske i Jugoslavije:

1) Već od kraja pedesetih, a osobito tijekom šezdesetih godina u sklopu Saveza komunista, posebno u Sloveniji i Hrvatskoj, jačaju tzv. reformske snage, koje se zalažu za djelomičnu decentralizaciju i protive državnom unitarizmu i forsiranju tzv. jugoslavenske kulture ${ }^{2}$, što će, uz ostalo, rezultirati i izglasavanjem novoga jugoslavenskog Ustava 1963. godine. Te su društveno-političke promjene dovele i do stanovite liberalizacije tadašnjih medija u Hrvatskoj, ${ }^{3}$ što je u zakonskome smislu bilo vidljivo i u donošenju novoga Zakona o štampi i drugim oblicima informacija 31. listopada 1960. godine. ${ }^{4}$ Njime je bilo određeno da svi građani imaju pravo izdavati novine i druge oblike tiska te osnivati i upravljati ustanovama i organizacijama za objavljivanje i širenje informacija. ${ }^{5}$

2) Drugi proces koji je obilježio šezdesete godine, a relevantan je za temu ovoga rada, bila je obnova dijaloga komunističkih vlasti i Katoličke crkve u brojnim zemljama Srednje i Istočne Europe. U odnosima Jugoslavije i Katoličke crkve taj će proces rezultirati i potpisivanjem „Protokola o razgovorima koji su vođeni između predstavnika vlade SFRJ i predstavnika Svete Stolice” 25. lipnja 1966., a potom i uspostavom punih diplomatskih odnosa između Socijalističke Federativne Republike Jugoslavije (SFRJ) i Svete Stolice 14. kolovoza 1970. godine. ${ }^{6}$

No, spomenuti procesi ne znače da je Hrvatska, kao dio tadašnje Jugoslavije, postala liberalno-građanska zemlja te stanovitu „liberalizaciju” tiska u tadašnjoj Hrvatskoj i Jugoslaviji ne treba shvatiti u smislu uspostave pune slobode medija i demokratizacije društva. Država je na različite načine i dalje kontrolirala djelovanje medija, a nastojala je ograničavati i djelovanje Katoličke crkve, osobito u javnoj sferi, odnosno u tadašnjem društvu.

1 Usp. MIKIĆ, „Crkveno i društveno značenje Glasa Koncila”, 22-39; MATAUŠIĆ, „Prihvat Drugog vatikanskog koncila”, 500; MATAUŠIĆ, „Katolički tisak u Zagrebačkoj nadbiskupiji”, 656.

2 Usp. RADELIĆ, Hrvatska u Jugoslaviji, 360-361.

3 Usp. MIHALJEVIĆ, „Liberalizacija i razvoj medija”, 239-258.

4 Službeni list FNRJ (Beograd), 45 (1960).

5 Usp. NOVAK, Hrvatsko novinarstvo u 20. stoljeću, 597. I tadašnji glavni urednik Glasa Koncila Vladimir Pavlinić ističe važnost Zakona o štampi: „Novo se razdoblje relativne slobode štampe u Jugoslaviji otvorilo s novim Zakonom o štampi i drugim sredstvima informacije, izdanom 1960. godine. Ni prethodnim Zakonom o štampi nije sve to bilo zabranjeno, ali novim Zakonom bilo je izričito dopušteno.” Usp. PAVLINIĆ, „Katolička štampa u Hrvatskoj”, 66.

6 Usp. ANCIĆ, „Pregovori i ponovna uspostava diplomatskih odnosa”. 
Razdoblje koje je predmet interesa ovoga rada obilježit će i slom tzv. hrvatskoga proljeća krajem 1971., što će rezultirati i ponovnim jačanjem represije režima nad brojnim javnim djelatnicima u Hrvatskoj, pa i brojnim sudskim procesima medijima i novinarima, ali i ponovnim pogoršanjem odnosa između države i Crkve. ${ }^{7}$

Premda su vlasti i na druge načine pokušale utjecati na uređivačku politiku pojedinih katoličkih glasila - iznošenjem prigovora na pojedine članke i autore na susretima državnih i crkvenih predstavnika, pritiscima i prijetnjama „administrativnim mjerama" koje su izricane u razgovorima predstavnika vlasti s pojedinim urednicima i katoličkim novinarima, kritikama koje su na račun djelovanja Katoličke crkve i njezinih medija iznošene u društvenom tisku ${ }^{8}-u$ ovome radu ograničit ću se na sudske procese protiv katoličkih listova, urednika i autora, uz prethodnu analizu djelovanja Komisije za vjerska pitanja Izvršnoga vijeća Socijalističke Republike (SR) Hrvatske (dalje u tekstu: Komisija za vjerska pitanja ili, skraćeno, Komisija), koja je te postupke najprije razmatrala i pripremala, a poslije uglavnom i inicirala. ${ }^{9}$ Pojedini sudski postupci obrađeni u ovome radu i do sada su, barem rubno, obrađivani i spominjani u različitim objavljenim publikacijama, ${ }^{10}$ no pritom, osim sudskoga postupka Živku Kusti$c^{c} u^{11}$, nisu bili podrobnije analizirani na temelju samih sudskih spisa. Stoga ću se u radu uglavnom služiti metodom deskripcije i analize većinom neobjavljenoga arhivskoga gradiva - zapisnika sa sjednica državnih tijela i sastanaka državnih i crkvenih predstavnika, sudskih spisa pohranjenih u različitim državnim i crkvenim arhivima - ali i analizom i komparacijom tadašnjih zakonskih propisa te pojedinih (inkriminiranih) članaka u tadašnjem katoličkom tisku.

7 Usp. AKMADŽA, Katolička crkva u komunističkoj Hrvatskoj, 391-425.

8 Usp. MIKIĆ, „Crkveno i društveno značenje Glasa Koncila”, 388-425.

9 Usp. Isto, 426-454. No, barem u jednom slučaju Komisija se osuđujućoj prvostupanjskoj presudi protiv jednoga katoličkog časopisa i usprotivila, žaleći se na činjenicu da ju Javno tužilaštvo pri podizanju optužnice uopće nije kontaktiralo te zaključujući da je ta presuda štetna i da „treba odlučiti da drugostepena presuda bude takva i takva”, uz dodatak da je „druga [je] stvar kako formulirati tu preporuku, kad je po zakonu ne smijemo dati”. Riječ je o Bogoslovskoj smotri (35/1965/, br. 1), u kojoj su „sporni” bili članci Jordana Kuničića o obitelji i Karla Nole o pobačaju, no kako za sada nisam prikupio dovoljno materijala za rekonstrukciju toga sudskog postupka, u ovom ga radu ne obrađujem. Usp. HR-HDA-310-KOVZ, kut. 67, Pov. br. 63/1966, Zapisnik Sjednice Komisije, 22. 3. 1966., 34-40, citat na str. 39.

${ }^{10}$ Usp. AKMADŽA, Katolička crkva u komunističkoj Hrvatskoj, 329, 436-439; MIKLENIĆ, Pogledi u Glas Koncila, 42-44; GRBELJA, Cenzura u hrvatskom novinstvu, 147-148, 151, $153-$ $154,173$.

${ }^{11}$ Usp. HUDELIST, Rim, a ne Beograd, 202-224. 
Praćenje rada katoličkoga tiska i razmatranje mjera protiv katoličkih listova i autora kao „prethodnica” sudskih postupaka

Djelovanje vjerskih zajednica i vjerskoga, a osobito katoličkoga tiska s velikom su pozornošću pratile državne vlasti tadašnje Hrvatske i Jugoslavije, što je vidljivo iz arhivske ostavštine Komisije za vjerska pitanja. Komisija je pozorno pratila osnivanje, način djelovanja, nakladu i distribuciju te, dakako, sadržaj katoličkih listova. Praćenje i analiza sadržaja organizirani su zajedno s Javnim tužilaštvom SR Hrvatske, koje je najprije, za interne potrebe ${ }^{12}$, priređivalo tzv. Mjesečne informacije, a od 1968. Komisija priređuje i Informativni bilten, u kojem su prenošeni najvažniji članci iz vjerskoga tiska, kao i svjetovnoga tiska kada bi se on bavio vjerskim temama. Sve je to potom bilo predmetom ne samo sjednica Komisije nego bi - najčešće u formi zasebnih analiza - bilo dostavljano i drugim partijskim i državnim institucijama. U „Mjesečnim informacijama” analizirane su i tzv. skrivene poruke ili „krajnje namjere” pojedinih članaka, pri čemu su njihovi autori često upozoravali na to da je neki članak ,izašao iz dozvoljenog područja", te je sugerirano da bi trebalo pokrenuti i sudske postupke protiv lista ili pojedinih autora. Primjerice, analizirajući izvješće Glasa Koncila o hodočašću u Svetu zemlju ${ }^{13}$, autor "Mjesečnih informacija” primjećuje da je na fotografiji, kao i u tekstu, istaknuta "hodočasnička zastava” koja se sastoji „od grba Svete zemlje i njemu dodate hrvatske trobojnice, ali bez crvene petokrake zvijezde”, te zaključuje da je riječ o "povredi ustavne odredbe”. ${ }^{14}$ No, kako za tu povredu nisu određene konkretne sankcije, autor se pita „da li ta povreda može predstavljati kriv. djelo zloupotrebe vjere i Crkve u političke svrhe" ili „kriv. djelo povrede ugleda države, njenih organa i predstavnika” ili „izražavanja nacionalne, rasne ili vjerske netrpeljivosti, mržnje i razdora", ili barem smatrati „prekršajem protiv javnog reda i mira”, te zaključuje: „O ovom pravnom i političkom pitanju raspravljat će stručni kolegij Javnog tužilaštva Hrvatske, na kojem će se zauzeti određeni stav, da li se radi o krivičnoj odnosno prekršajnoj odgovornosti, ili bi to trebalo da riješe politički forumi."15

I nešto prije, $\mathrm{u}$ „Informaciji o izdavačkoj djelatnosti vjerskih zajednica u SRH” iz sredine 1966., moguće je uočiti većinu glavnih zamjerki koje su državne vlasti imale kada je katolički tisak u pitanju. Primjerice, vjerskim listovima zamjera se učestalo tretiranje političkih tema, osobito u svijetu, pri čemu se „daje veliki publicitet teškoćama i 'progonima' koje u tim zemljama navodno doživljavaju katolički svećenici”, što je, kako se dodaje, „u suprotnosti s našim vanjsko-političkim odnosima s tim zemljama”. ${ }^{16}$ „Još uvijek ima i primjera da

\footnotetext{
${ }^{12} \mathrm{U}$ Arhivu Komisije ta su izdanja smještena među povjerljive spise.

${ }^{13}$ Usp. „Hodočašće u Svetu zemlju”, Glas Koncila (Zagreb), 30. 4. 1967., 1, 8-9.

${ }^{14}$ HR-HDA-310-KOVZ, kut. 72, Pov. 52/1967, „Mjesečne informacije o aktivnosti i pisanju vjerske štampe za razdoblje od 1.-31. V. 1967.," god. V, br. 5, Zagreb, svibanj 1967., 1.

${ }^{15}$ Isto, 2.

${ }^{16}$ HR-HDA-310-KOVZ, kut. 67, Pov. br. 64/1966, Informacija o izdavačkoj djelatnosti vjerskih zajednica u SRH, 26. 5. 1966., 6.
} 
pojedini autori spominju Stepinca i pozivaju se na njega kao velikog dobročinitelja Katoličke crkve i hrvatskog naroda”, ${ }^{17}$ kaže se među ostalim u „Informaciji” te se zaključuje:

„Opća karakteristika sadržaja svih vrsta izdanja katoličke štampe je da su često dvosmislena i obojena tipično crkvenom bojom. Prezentirana su tako da povećaju naklonost prema Katoličkoj crkvi i da kod vjernika utječu na formiranje političkih stavova ${ }^{18}$ koji odgovaraju stavovima Katoličke crkve i koji često nisu i ne mogu biti u skladu s našim pozitivnim zakonodavstvom i našim shvaćanjima i stremljenjima, jer polaze s ideološki sasvim suprotnih pozicija." ${ }^{19}$

\section{Pokušaji određivanja „dopuštenih granica” sadržaja vjerskoga tiska}

Tijekom 1966. i 1967. na više sjednica Komisije razmatralo se i pitanje kada katolički mediji svojim sadržajem izlaze „izvan granica zakona”, odnosno smije li se vjerski tisak uopće baviti pitanjima koja nisu striktno vjerskoga karaktera.

Tako je na sjednici 22. ožujka 1966., koja je nastavljena 29. ožujka, Komisija zauzela stajalište da je, primjerice, karitativnom akcijom „Tko je moj bližnji?” pokrenutom u Glasu Koncila „Crkva prešla okvire svog djelovanja određene našim pravnim propisima i prešla na područje rezervirano isključivo za naše društvene institucije”. ${ }^{20}$ Komisija je zaključila i da dječji časopis Mali koncil „svojim sadržajem prelazi okvire koji su za vjersku štampu određeni postojećim pravnim propisima" ${ }^{21}$

$\mathrm{Na}$ istoj sjednici tajnik Komisije Ivan Lazić izvijestio je da se na prije održanom sastanku - na kojem su uz članove Komisije sudjelovali i predstavnici Centralnoga komiteta Saveza komunista Hrvatske (CK SKH) i Socijalističkoga saveza radnog naroda Hrvatske (SSRNH) te predsjednici Vijeća za prekršaje, Okružnoga suda, republičkoga i okružnoga javnog tužilaštva ${ }^{22}$ - „nije [se] došlo do sigurnog pouzdanog mjerila” ${ }^{23}$ kada vjerski tisak izlazi iz „dopuštenih” okvira te su ponovno došle do izražaja nejasnoće zakonskoga uređenja toga pitanja. Naime, kako je objasnio, tisak je po Ustavu SFRJ u načelu slobodan, pa tako i tisak vjerskih zajednica. No, kako je dodao, „drugovi su također rekli, ako se nađe da je politički oportuno, može se pisanje određenih

\footnotetext{
17 Isto, 7.

18 Podcrtavanje je preuzeto iz izvornoga teksta.

${ }^{19}$ Isto, 9.

${ }^{20}$ HR-HDA-310-KOVZ, kut. 67, Pov. br. 63/1966, Zapisnik Sjednice Komisije, 22. 3. 1966., 34.

21 Isto.

${ }^{22}$ Riječ je o sastanku održanom 18. ožujka 1966. u Zagrebu, na kojem su uz vodstvo Komisije bili predsjednik Okružnoga suda Vjekoslav Vidović, predsjednik Vijeća za prekršaje Stjepan Potočki, republički javni tužilac, predsjednik Okružnoga javnog tužilaštva te predstavnici Sekretarijata unutrašnjih poslova, CK SKH i SSRNH. Usp. HR-HDA-310-KOVZ, kut. 67, Pov. br. 63/1966, Zapisnik sa sastanka, 18. 3. 1966.

${ }^{23}$ HR-HDA-310-KOVZ, kut. 67, Pov. br. 63/1966, Zapisnik Sjednice Komisije, 22. 3. 1966., 21.
} 
vjerskih listova ograničiti i za to bi se moglo naći osnova u postojećim zakonima o štampi i izdavačkim poduzećima i ustanovama”. ${ }^{24}$

Iz jednoga kasnijeg izvješća Javnoga tužilaštva, koje je Komisija razmatrala 8. travnja 1967., još je jasnije zašto je, pravno gledano, tadašnjim vlastima bio problem jednoznačno se odrediti prema pitanju smije li se vjerski tisak uopće baviti pitanjima koja nisu striktno vjerskoga karaktera. U izvješću se, naime, u poglavlju naslovljenom „Problem granica u kojima se može kretati pisanje vjerske štampe" 25 , analiziraju pojedine odredbe Zakona o pravnom položaju vjerskih zajednica ${ }^{26}$ (čl. 3., st. 2.), Zakona o izdavačkim poduzećima i izdavačkim ustanovama ${ }^{27}$ (čl. 48.) te Zakona o štampi i drugim oblicima informacija ${ }^{28}$ (čl. 23., st. 2.; čl. 52.) te se zaključuje da u pitanju zakonske mogućnosti ograničavanja sadržaja vjerskoga tiska isključivo na vjerske teme postoje dva različita stava pravnih stručnjaka:

„Prema jednom, vjerske zajednice mogu izdavati i raspačavati samo vjersku štampu, tj. vjerske novine i drugu periodiku koja po prirodi stvari može imati samo takav informativni sadržaj koji je od interesa za vjersku djelatnost i mogu izdavati samo one publikacije koje služe vjerskoj nastavi, vršenju vjerskih obreda ili vjerskih poslova. Izlaženje iz ovih okvira znači prelaženje na područje opće novinsko izdavačke odnosno društveno-političke djelatnosti, na što vjerske zajednice nisu ovlaštene." ${ }^{29}$

No, po drugome stavu „izdanja vjerskih zajednica mogu sadržavati sve ono što ne nanosi štetu našem društvu, tj. ograničena su istim ogradama kao sva ostala naša štampa”. ${ }^{30} \mathrm{Na}$ kraju se zaključuje da je „pitanje granica u kojima se može kretati pisanje vjerske štampe i dalje otvoreno i složeno, ne samo sa stanovišta postojećih pravnih propisa, već i sa stanovišta političkih odnosa između Crkve i države"." 11

Rasprave o „okvirima u kojima se može kretati pisanje vjerske štampe” trajat će sve do početka 1972., kada će Komisija na sjednici održanoj 25. siječnja zaključiti da, s obzirom na to da je

„[...] granice pisanja vjerske štampe [je] teško odrediti, u praksi će se poduzimati zahvati protiv vjerske štampe samo u onim slučajevima u kojima se u toj štampi pojave članci neprijateljskog ili drugog sličnog karaktera, odnosno kad se

\footnotetext{
24 Isto, 22.

${ }^{25}$ HR-HDA-310-KOVZ, Zapisnici sa sjednica Komisije (knjiga 9), „Izdavačka djelatnost vjerskih zajednica u SRH”, Prilog 5 Sjednici Komisije, 8. 4. 1967., 5 (53). U slučaju knjiga zapisnika najprije navodim broj stranice samoga pojedinačnog zapisnika, a potom u zagradama i broj stranice koja je naknadno dodana nakon što je dokument uvezan u knjigu.

26 Službeni list FNRJ, 22 (1953).

27 Službeni list FNRJ, 44 (1959).

${ }^{28}$ Službeni list FNRJ, 45 (1960).

${ }^{29}$ HR-HDA-310-KOVZ, Zapisnici sa sjednica Komisije (knjiga 9), „Izdavačka djelatnost vjerskih zajednica u SRH”, Prilog 5 Sjednici Komisije, 8. 4. 1967., 6 (54).

30 Isto.

${ }^{31}$ Isto, 7 (55).
} 
steknu uslovi na osnovu čl. 52. Zakona o štampi i drugim sredstvima informiranja, što znači da pisanje vjerske štampe nije ničim više ograničeno nego što je i pisanje ostale štampe". ${ }^{32}$

\section{Sudski postupci protiv katoličkih listova, urednika i novinara}

Kako sam prikazao, državne vlasti, uključujući i Javno tužilaštvo, od sredine šezdesetih godina intenzivno su razmatrale mogućnosti pravnoga sankcioniranja pisanja katoličkoga tiska, osobito u pogledu „prekoračivanja vjerskog djelokruga”, a pravna mišljenja o tome je li i zakonski nedvojbeno kažnjivo tretiranje „nevjerskih” tema na stranicama vjerskoga tiska bila su podijeljena. Sudeći po presudama koje ću prikazati u nastavku rada, krajem 1967. vlasti su ipak odlučile primijeniti „strože” gledanje na pitanje dopustivosti „prekoračivanja vjerskog djelokruga" u katoličkom tisku.

Zabrana raspačavanja i zapljena „Glasnika sv. Antuna Padovanskoga” br. 12/1967 i kazneni postupak protiv njegova glavnoga urednika Ivona (Ivana) Cuka ${ }^{33}$

Prvu zabranu od komunističkih vlasti nakon obnove katoličkoga tiska doživio je mjesečnik Glasniksv. Antuna Padovanskoga krajem 1967. godine. Zbog tri članka objavljena u br. 12 (tiskan krajem studenoga za prosinac te godine) - „Dva sata u procjepu”, „Neobičan sudar u Ujedinjenim nacijama” i „Pismo omladinca” - Okružno javno tužilaštvo u Zagrebu 24. studenog 1967. svojim je rješenjem (Ktr br. 1050/67) privremeno zabranilo raspačavanje toga broja. Tu je odluku 27. studenog potvrdio i Okružni sud u Zagrebu naloživši zapljenu i uništenje cjelokupne naklade toga broja lista. ${ }^{34}$ Kako stoji u obrazloženju rješenja Okružnoga suda, u tim se člancima iznose „lažne i izopačene tvrdnje o položaju vjere i vjerskih zajednica u državama sa socijalističkim društvenim uređenjem, kao i položaja nacionalnih manjina u Sovjetskom Savezu, zatim neistinite i izopačene ocjene ideoloških ocjena rata na Srednjem istoku i rata u Vijetnamu, kao i neistinite i izopačene tvrdnje o moralnoj vrijednosti socijalističkog sistema obrazovanja" ${ }^{35}$ te su se, kako se kaže dalje, stekli uvjeti za zabranu raspačavanja iz čl. 52. Zakona o štampi i drugim oblicima informacija.

${ }^{32}$ HR-HDA-310-KOVZ, kut. 94, Pov. br. 37/1972, Zabilješka sa sastanka Komisije s Tužilaštvom SRH, 25. 1. 1972.

${ }^{33} \mathrm{U}$ sudskim spisima njegovo se ime navodi kao Ivan, no on sam nazivao se imenom Ivon te je pod tim imenom poznat u crkvenim i publicističkim krugovima, pa i ja u radu koristim tu inačicu njegova imena.

${ }^{34}$ Usp. HR-HDA-310-KOVZ, kut. 184, br. 43/1968, Rješenje Okružnog suda u Zagrebu br. KR-47/1967 od 27. studenog 1967., 1.

${ }^{35}$ Isto, 6. 
Protiv toga rješenja Provincija franjevaca konventualaca u Zagrebu, kao nakladnik, uložila je žalbu Vrhovnom sudu Hrvatske, no on ju je odbacio te svojom presudom potvrdio odluku Okružnoga suda. ${ }^{36}$

Zbog spornih članaka u zabranjenom broju Glasnika sv. Antuna Padovanskoga Okružno javno tužilaštvo podignulo je i kaznenu prijavu protiv glavnoga i odgovornoga urednika lista, svećenika Ivona Ćuka, te ga je Općinski sud I. u Zagrebu presudom od 5. ožujka 1968. osudio na devet mjeseci zatvora. ${ }^{37}$ Kako je vidljivo iz obrazloženja presude (br. KT-16047/1967), Ćuk je osuđen zbog kaznenoga djela iz čl. 311. Krivičnoga zakonika ${ }^{38}(\mathrm{KZ})$ : „Zloupotreba vjere i crkve u političke svrhe" ${ }^{39}$, a kao pravnu osnovu na temelju koje je presuda izrečena Općinski sud I. u Zagrebu naveo je:

1) u samome tekstu presude Ustav SFRJ ${ }^{40}$ : čl. 40 ., st. $3 .{ }^{41}$ i čl. $46 .$, st. $4 .{ }^{42}$, a u njezinu obrazloženju navode se i st. 1. i 2. istoga članka ${ }^{43}$

2) Zakon o pravnom položaju vjerskih zajednica, i to: u samoj presudi čl. 5., koji je zabranjivao „zloupotrebu vjerske štampe i vjerskih osjećaja u političke svrhe”, a u obrazloženju i čl. 2. („djelatnost vjerskih zajednica mora biti u sladu s Ustavom i zakonima”) i čl. 3. („vjerske zajednice mogu izdavati i raspačavati vjersku štampu u pogledu koje vrijede opći propisi o štampi”) ${ }^{44}$

3) Zakon o štampi i drugim oblicima informacija, i to: u tekstu same presude čl. 2., st. 2. (pravo na širenje informacija „pod uvjetima što ih predviđa

${ }^{36}$ Uvid u žalbu i presudu Vrhovnoga suda (br. KŽ-1652/1967) nisam imao, no o njihovu postojanju doznajem iz obrazloženja presude Općinskoga suda I. u Zagrebu br. K-229/68 Ivonu Ćuku. Usp. HR-HDA-310-KOVZ, kut. 184, br. 43/1968.

${ }^{37}$ Usp. HR-HDA-310-KOVZ, kut. 184, br. 43/1968, Presuda Općinskog suda I. u Zagrebu br. K-229/68, 5. 3. 1968., 3. Presliku presude, zajedno s tekstom žalbe Okružnom sudu u Zagrebu od 25. ožujka 1968. te molbom da, ako bude u prilici, njegov slučaj spomene članovima Komisije za vjerska pitanja „kako bi se kazna pri žalbenom postupku izmijenila barem u uvjetnu”, Ivon Ćuk je, uz napomenu da su i presuda i žalba zanimljive s „obzirom na našu vjersku štampu”, dostavio i kardinalu Franji Šeperu 4. travnja 1968. godine. Vidi u: HR-NAZ, Prezidijal Šeper, br. 36/1968./Pr.

38 „Krivični zakonik”, Službeni list FNRJ, 13 (1951); „Zakon o izmjenama i dopunama Krivičnog zakonika", Službeni list FNRJ, 30 (1959).

${ }^{39}$ Cijeli čl. 311. glasi: „Vjerski predstavnik koji zloupotrijebi slobodu vršenja vjerskih poslova ili vjerskih obreda u svrhe protivne ustavnom poretku, kaznit će se zatvorom.” Po KZ-u iz 1951. bilo je određeno „... do dvije godine” (Službeni list FNRJ, 13 /1951/), no njegovim izmjenama i dopunama iz 1959. to je vremensko ograničenje ukinuto (usp. čl. 224., Službeni list FNRJ, 30 /1959/).

40 Službeni list SFRJ (Beograd), 14 (1963).

${ }^{41}$ „Ovim slobodama i pravima nitko se ne smije koristiti radi rušenja osnova socijalističkog demokratskog uređenja utvrđenog ovim ustavom, radi ugrožavanja mira, ravnopravne međunarodne suradnje ili nezavisnosti zemlje, raspirivanja nacionalne, rasne ili vjerske mržnje ili netrpeljivosti, ili radi podsticanja na vršenje krivičnih djela, niti na način kojim se vrijeđa javni moral."

42 „Protuustavna je zloupotreba vjere i vjerske djelatnosti u političke svrhe.”

43 „Ispovijedanje vjere je slobodno i privatna stvar svakog čovjeka” „Vjerske zajednice odvojene su od države i slobodne u vršenju vjerskih poslova i vjerskih obreda."

${ }^{44}$ „Zakon o pravnom položaju vjerskih zajednica”, Službeni list FNRJ, 22 (1953). 
zakon”), a u obrazloženju i čl. 7., koji je isticao da „objavljivanje informacija koje nanose štetu [...] interesima društvene zajednice predstavlja zloupotrebu slobode informacija". ${ }^{45}$

U obrazloženju presude sporni su članci Glasnika sv. Antuna Padovanskoga opisani na isti način na koji ih je u rješenju o zabrani okarakterizirao Okružni sud, a Ćuk je proglašen krivim jer je „kao vjerski predstavnik zloupotrijebio slobodu vršenja vjerskih poslova u svrhe protivne ustavnom poretku” ${ }^{46}$ odnosno „zloupotrijebio je vjeru i Crkvu u političke svrhe”, ${ }^{47}$ a takvo je djelovanje, po ocjeni suda, ne samo protuzakonito nego i protuustavno. Sud naime, kako izričito stoji u obrazloženju presude, smatra „da u vjerski list ne spada komentiranje političkih događaja, te da je prema tome uvrštavanje svakog članka u kojem se tako nešto iznosi protivno Ustavu, Zakonu o štampi i drugim oblicima informacija i Osnovnom zakonu o pravnom položaju vjerskih zajednica". ${ }^{48}$ Dakle, po mišljenju suda, Glasnik sv. Antuna Padovanskoga je vjerski list te je „logično [je] i jedino dopustivo da se [...] bavi isključivo vjerskom tematikom”. ${ }^{49}$ Sud, doduše, priznaje da je vrlo teško „distancirati što bi trebalo spadati u vjersku tematiku u jednom širem smislu, ali je sasvim sigurno da komentiranje političkih događaja nikako ne može spadati u vjersku tematiku, pogotovo ne kada takvi komentari prelaze granice dozvoljenog i pretvaraju se u serviranje maglovitih poluistina, pa kroz to unose dezinformacije među čitaoce" ${ }^{50}$ Kao otegotna okolnost u presudi iznosi se činjenica da je „okrivljeni do sada u dva navrata kažnjavan po sucu za prekršaje zbog nedopuštenih i nezakonitih istupa u vjerskoj štampi i to upravo u istom Glasniku svetog Antuna Padovanskog i to u svojstvu glavnog i odgovornog urednika tog lista ${ }^{51}$, što ga nije navelo da razmisli i korigira svoje istupe i tematiku ograniči na vjersku tematiku, već je i dalje uporno u vjerskom listu nametao i obrađivao protuustavnu i nedopuštenu tematiku, te činjenicu da je kroz širenje dezinformacija i poluistina u vjerskom listu pokušao utjecati na formiranje javnog mijenja čitalaca - vjernika". ${ }^{52}$

U svojoj žalbi Okružnom sudu u Zagrebu od 25. ožujka 1968. Ivon Ćuk pokušao je, među ostalim, pobiti takvo shvaćanje odvojenosti Crkve i države i ograničenja tematike kojom se smije baviti vjerski tisak. Tako se u točki 7 svoje žalbe pozvao na čl. 40. Ustava, kojim je „zajamčena sloboda štampe, sloboda govora, javnog istupanja” te "građanima pripada pravo da putem sredstava in-

\footnotetext{
45 „Zakon o štampi i drugim oblicima informacija”, Službeni list FNRJ, 45 (1960).

${ }^{46}$ HR-HDA-310-KOVZ, kut. 184, br. 43/1968, Presuda Općinskog suda I. u Zagrebu br. K-229/68, 5. 3. 1968., 2.

${ }^{47}$ Isto, 3.

${ }^{48}$ Isto, 5.

${ }^{49}$ Isto, 4.

50 Isto.

${ }^{51}$ Nažalost, nije mi poznato o kojim se prekršajnim postupcima radilo niti zbog kojih su konkretnih tekstova pokrenuti.

${ }^{52}$ HR-HDA-310-KOVZ, kut. 184, br. 43/1968, Presuda Općinskog suda I. u Zagrebu br. K-229/68 od 5. ožujka 1968., 6.
} 
formacija izražavaju i objavljuju svoja mišljenja, te se koriste sredstvima informacija, da izdaju novine i drugu štampu, šire informacije itd." ${ }^{33}$

Osim toga Ćuk u svojoj žalbi pita „da li se štampanje i izdavanje ovakova časopisa smatra 'vršenjem vjerskog posla'?" i odmah nudi svoj odgovor:

„Onaj tko izdaje i štampa bilo novine, časopis itd. bavi se poslom propisanim Zakonom o štampi i za nj važe odredbe toga zakona, jer se bavi izdavačko-štamparskim poslom. Zakon ne pozna vrste štamparskog posla po sadržaju, po tematici o kojoj štampa radi niti to propisuje nego jedino poznaje izdavačko-štamparski posao pa tako ne poznaje niti vjerski izdavačko-štamparski posao, pa prema tome vršenje izdavanja i štampanja jedne edicije sa vjerskom tematikom nije vjerski posao nego štamparski." 54

Stoga zaključuje da „vjerski predstavnik koji se bavi štampanjem i izdavanjem potpada za svoj rad pod propis Zakona o štampi itd. i ako počini kakovo krivično djelo, odgovarat će za taj svoj čin po propisima Zakona o štampi kao svaki drugi građanin, ali je također jasno da on ne može radi toga što je vjerski predstavnik biti stavljen u gori položaj od drugih građanskih izdavača i štampara"..55

Kako bi upozorio na apsurdnost presude kojom je osuđen na zatvorsku kaznu, Ćuk u žalbi Okružnom sudu skreće pozornost i na činjenicu da ,inkriminiranim krivičnim djelom nije nastala nikakva šteta, da nisu nastale nikakve štetne posljedice niti su mogle nastati, jer je cijela naklada broja 12 Glasnika uzapćena i poništena" ${ }^{36}$ prethodnom sudskom odlukom o zabrani raspačavanja i zapljeni toga broja lista.

Nažalost, daljnji tijek sudskoga postupka nisam uspio potpuno rekonstruirati jer mi je bila nedostupna odluka Okružnoga i, eventualno, Vrhovnoga suda na žalbu Ivona Ćuka. Iz sekundarnih izvora doznajem da je presuda Općinskoga suda preinačena, no autori koji su taj sudski postupak spominjali ne slažu se o sadržaju te preinake. Naime, Šimun Penava kaže da je presuda Općinskoga suda „zamijenjena uvjetnom kaznom”, ${ }^{57}$ a Nikola Mate Roščić tvrdi da je „nakon žalbe ta kazna preinačena u novčanu kaznu”. ${ }^{8}$

${ }^{53}$ HR-NAZ, Prezidijal Šeper, br. 36/Pr/1968., Žalba Ivona Ćuka na Presudu Općinskog suda I. u Zagrebu br. K-229/68, 25. 3. 1968., točka 7. Žalba je sastavljena na devet stranica, koje nisu označene brojevima, ali je koncipirana u 23 brojevima označene točke, pa se i ja u navođenju, umjesto stranicama, služim tim brojevnim oznakama.

${ }^{54}$ Isto, točka 10.

${ }^{55}$ Isto, točka 11 .

${ }^{56}$ Isto, točka 22.

${ }^{57}$ U: PENAVA, „Žrtve poratne represije”, 160.

${ }^{58}$ U: ROŠČIĆ, „O. Ivon Ćuk”, 596. 


\section{Prekršajni postupak protiv nakladnika i odgovornoga urednika „Maloga koncila"}

Da će sudske vlasti pisanje o društveno-političkim događajima u vjerskome tisku i ubuduće tretirati kao nedopušteno ponašanje svjedoči i rješenje suca za prekršaje Skupštine grada Zagreba od 19. studenog 1968., koji je ukorom kaznio Nadbiskupski duhovni stol u Zagrebu kao izdavača i biskupa Franju Kuharića kao odgovornoga urednika lista Mali koncil zbog objave članka „Inkvizicija više nije važna” u br. 9 iz 1968. jer su njime, kako se ističe, „došle do izražaja društveno-političke pretenzije vjerske štampe". ${ }^{59}$

Zahtjev za pokretanje prekršajnoga postupka dalo je Okružno javno tužilaštvo u Zagrebu. ${ }^{60}$ Kako stoji u obrazloženju rješenja, sudac ih je „proglasio krivim, jer se u postupku uvjerio, da se u članku 'Inkvizicija više nije važna' raspravlja o okupaciji u SR Čehoslovačkoj [ČSSR, op. A. M.], Vijetnamu i Bijafri sa društveno-političkog stanovišta. Ustavom SFRJ (član 46.) i citiranim zakonskim propisom ${ }^{61}$ zakonodavac je jasno razlučio sveru [sferu, op. A. M.] privatizacije Crkve od države i isključio bilo kakove društveno-političke pretenzije vjerskoj štampi, svodeći njen sadržaj isključivo na katehizaciju, pa kako je citirani članak prešao ove okvire, to je trebalo riješiti kao u dispozitivu". ${ }^{62}$ Kao olakotnu okolnost sudac je u obrazloženju iznio da spornim člankom „nisu prouzrokovane teže posljedice", ${ }^{33}$ pa je primijenio blaži oblik kazne za oba okrivljenika - Nadbiskupski duhovni stol kao izdavača te biskupa Kuharića kao odgovornoga urednika - kaznu ukora.

Inače, kako se također kaže u obrazloženju, Kuharić je u raspravi poricao krivnju „navodeći da spominjanje suvremenih događaja u citiranom članku, o događajima u Čehoslovačkoj, Vijetnamu i Bijafri nisu tretirani sa političkog aspekta, niti sa političkom nakanom, već sa etičkog aspekta, pošto vjerski odgoj čovjeka smatra integralnim, kako bi čovjek znao zauzeti stanovište samo u svjetlu moralnih načela o događajima iz konkretnog života”. ${ }^{64}$

Zbog toga je slučaja Komisiju 6. listopada 1968., prije donošenja rješenja, posjetio i glavni urednik Glasa Koncila Vladimir Pavlinić, a primio ga je predsjednik republičke Komisije Stjepan Iveković. Kako stoji u zabilješci s toga susreta, i Pavlinić je iznio stav da se u „spornim” člancima Maloga koncila „ne

${ }^{59}$ HR-HDA-310-KOVZ, kut. 75, Pov. br. 27/1968, Informativni bilten, br. 3/1968., 2.

${ }^{60}$ Informaciju o pokretanju zahtjeva sucu za prekršaje Okružno javno tužilaštvo u Zagrebu dostavilo je 23. listopada 1968. i Službi državne sigurnosti, Centar Zagreb. Vidi u: HR-NAZ, Ostavština Franje Kuharića, Dosje UDBA-e i Službe državne sigurnosti o Franji Kuhariću, uvezani dokumenti - dar ministra Ivana Jarnjaka, Zagreb, 1995., 142.

${ }^{61} \mathrm{U}$ presudi se kao pravna osnova za postupak navodi Osnovni zakon o izdavačkim poduzećima i izdavačkim ustanovama, čl. 58. i čl. 56., st. 1. i 2., kao i Osnovni zakon o prekršajima, čl. 34 .

${ }^{62} \mathrm{U}$ navođenju se služim Rješenjem suca za prekršaje Skupštine grada Zagreba br. II/715607-15608-68 od 19. studenog 1968., koje nalazim u: HR-NAZ, Ostavština Franje Kuharića, Dnevničke zabilješke 1969-1973, korice 1, sveš. 5, 2.

${ }^{63}$ Isto.

${ }^{64}$ Isto. 
radi o političkim pitanjima nego im je bila namjera da te događaje objasne svojim čitaocima s etičkog aspekta”. ${ }^{65}$ Kako je dodao, „na isti način ove stvari tretiraju i u Glasu Koncila pa mu se čini da u tome nisu griješili”, te je poručio da se i njima u uredništvu čini „kao da je to zaoštravanje odnosa” i „ustupak 'staljinističkim snagama' da ih se tretira kao neprijatelje”. ${ }^{66}$ No, Iveković je odgovorio da je „čitavi postupak stvar nadležnih organa Tužilaštva i Suda, ali po njegovom mišljenju taj članak zaista je nelojalan i nepoćudan i nije ga trebalo objaviti”, te zaključio da "to nije nikakvo zaoštravanje odnosa nego kršenje propisa” te da bi „redakcija trebala voditi računa i o stavu države prema određenim pitanjima, a posebno kod ove čisto političke teme”. ${ }^{7}$

\section{Sudske zabrane „Glasa Koncila” od 1970. do 1973. godine}

Od 1970. do 1973. u tri je navrata bilo zabranjeno raspačavanje cijelih brojeva Glasa Koncila (br. 21 iz 1972. i br. 7 i 12 iz 1973.), a u jednome slučaju samo „spornoga” članka (br. 4 iz 1970.). U svim tim slučajevima tijek sudskih postupaka izgledao je uglavnom isto: najprije bi zagrebačko Okružno javno tužilaštvo izdalo privremeno rješenje na temelju čl. 52., st. 1., toč. 2. i čl. 53. Zakona o štampi i drugim oblicima informacija („iznošenje lažnih tvrdnji kojima se izaziva uznemirenost građana”) - osim u zadnjem prikazanom slučaju (iz lipnja 1973.), kada je primijenjen novi Zakon o sprečavanju zloupotrebe slobode tiska i drugih oblika informacija ${ }^{68}$, o čemu će poslije biti više riječi - a potom bi Okružni sud ta rješenja, nakon provedene rasprave, u većoj ili manjoj mjeri potvrdio te naložio zabranu raspačavanja, oduzimanje i uništavanje tiskanih primjeraka broja (za br. 4/1970 samo arka sa spornim člankom) i rasturanje tiskarskoga sloga. U nekoliko navrata nakladnik lista, Nadbiskupski duhovni stol u Zagrebu, žalio se na ta rješenja Vrhovnome sudu Hrvatske, no sve su te žalbe bile odbijene kao neosnovane, uglavnom s istim ili sličnim obrazloženjima. U jednom je slučaju nakladnik od Saveznoga javnog tužilaštva u Beogradu zatražio da uloži zahtjev za zaštitu zakonitosti protiv rješenja Okružnoga i Vrhovnoga suda, no taj je prijedlog odbijen.

\section{Zabrana „Glasa Koncila” br. 4 od 22. veljače 1970.}

Okružno javno tužilaštvo Zagreb naložilo je 19. veljače 1970. (Rješenje br. KTR-152/70) privremenu zabranu raspačavanja Glasa Koncila br. 4 od 22. veljače 1970. godine. Kako stoji u rješenju, mjera je donesena zbog objave pri-

${ }^{65}$ HR-HDA-310-KOVZ, kut. 79, Pov. br. 228/1968, Zabilješka sa susreta Stjepana Ivekovića i Vladimira Pavlinića, 6. 10. 1968., 1. Pavlinićeva opaska o „staljinistima” očito se odnosi na tzv. unitariste, nasuprot tzv. reformistima unutar CK SKH. Postupke protiv katoličkoga tiska toga vremena u sličnom je kontekstu, kako ću poslije u radu prikazati, doživljavao i zagrebački (nad) biskup Franjo Kuharić.

66 Isto.

${ }^{67}$ Isto., 1-2.

${ }^{68}$ Službeni list SFRJ, 22 (1973). 
jevoda članka izvorno objavljenog u listu L'Osservatore Romano (11. veljače 1970. ${ }^{69}$ u kojem su

„[...] javni i politički istupi pok. kardinala i nadbiskupa zagrebačkog dr. Alojzija Stepinca za vrijeme neprijateljske okupacije Hrvatske 1941-1945. godine ocijenjeni kao djelovanje istaknutog pobornika protiv nacionalne, vjerske i rasne diskriminacije i zaštitnika hrvatskog naroda i ostalog stanovništva Hrvatske od terora okupatora i njegovih slugu, što je protivno činjeničnom stanju o njegovoj suradnji sa neprijateljem u tom vremenskom razdoblju utvrđenom pravomoćnom presudom Vrhovnog suda Hrvatske Stup 6/46 od 11. 10. 1946., [...] to je obzirom na okolnost da se radi o ličnosti najvišeg poglavara Rimokatoličke crkve u Hrvatskoj podobno da kod dijela vjernika i drugih građana pobudi nespokojstvo i ugrozi njihovo povjerenje u zakonit rad pravosuđa, dakle iznose lažna tvrđenja kojima se izaziva uznemirenost građana, čime je počinjeno djelo iz čl. 52. st. 1. toč. 2. Zakona o štampi i drugim oblicima informacija".70

Rasprava pred Okružnim sudom u Zagrebu održana je 23. veljače 1970. godine. Glas Koncila zastupao je odvjetnik Zlatko Kuntarić, a tročlano Vijeće udovoljilo je prijedlogu tužilaštva da se zabrani raspačavanje, no ne cijeloga broja nego tek spornoga članka. U rješenju se naime kaže da se, u skladu s čl. 61., st. 2. Zakona o štampi i drugim oblicima informacija „zabrana raspačavanja neće [se] primijeniti na ostale dijelove, nepovezane arke Glasa Koncila br. 4 koji se mogu odvojiti od strane 9, zbog koje je izrečena zabrana,", arak „ima se oduzeti i uništiti”" ${ }^{72}$ Po izjavama sadašnjega glavnog urednika lista Ivana Miklenića, uredništvo je potom organiziralo izrezivanje sporne stranice, pa su i preostali primjerci lista u tako skraćenom obliku pušteni u prodaju. ${ }^{73}$

Kako stoji u obrazloženju rješenja, pravni zastupnik Glasa Koncila negirao je tijekom rasprave navedene optužbe uz obrazloženje da je „članak prenesen [je] iz poluslužbenog vatikanskog dnevnika L'Osservatore Romano, koji je legalno unesen u našu zemlju i raspačavan. Da je članak suprotan Zakonu o štampi i da se njime izaziva uznemirenost građana, državni sekretar za unutrašnje poslove zabranio bi unošenje i raspačavanje", 74 što se nije dogodilo. Osim toga, zaključio je, „napadnuti članak ne iznosi niti pronosi lažne izopačene vijesti ili tvrdnje, pa prema tome nije podoban da izazove uznemirenost građana, već je naprotiv u duhu sporazuma naše zemlje sa Svetom Stolicom i ni u kom slučaju ne zloupotrebljava slobodu štampe". 75

\footnotetext{
${ }^{69}$ Usp. Fiorello CAVALLI, „Nikad nismo izgubili pouzdanje u Boga: Kard. Alojzije Stepinac, nadbiskup zagrebački - 10 godina od blažene smrti”, Glas Koncila, 22. 2. 1970., 9.

${ }^{70}$ Arhiv Glasa Koncila, ur. br. 20/70, Rješenje Okružnog javnog tužilaštva br. KTR-152/70, 19. 2. 1970., 1-2.

${ }^{71}$ Arhiv Glasa Koncila, ur. br. 20/70, Rješenje Okružnog suda br. KR-10/70, 26. 2. 1970., 4.

${ }^{72}$ Isto, 2.

${ }^{73}$ Usp. MIKLENIĆ, Pogledi u Glas Koncila, 43.

${ }^{74}$ Arhiv Glasa Koncila, ur. br. 20/70, Rješenje Okružnog suda br. KR-10/70, 26. 2. 1970., 3.

${ }^{75}$ Isto.
} 
Više pojedinosti sa same rasprave nalazimo u sažetku koji je pod naslovom „Činjenični i pravni supstrat” 6. ožujka 1970. sastavio odvjetnik Kuntarić. Iz njega je vidljivo da je predstavnik tužilaštva i za autora teksta Fiorella Cavallija ustvrdio da je poznat kao osporavatelj točnosti presude protiv Stepinca, o čemu je objavio i jedan novinski članak u Madridu 1947., kao i jednu knjigu o toj temi. ${ }^{76}$ U sažetku se, citirajući dio zapisnika s rasprave, kaže i da je Kuntarić izjavio da je dio članka s podnaslovom „Ljubav prema bližnjemu” zapravo temeljen na govoru nadbiskupa Stepinca od 30. listopada 1943., „koji je u stvari i održan kako je to u ono vrijeme [javila] preko radio stanica Slobodna Jugoslavija, zatim Engleska radio stanica $B B C$ i Agitprop. Narodno oslobodilačke borbe u letku, koji je slao svojim jedinicama”. ${ }^{77} \mathrm{Na}$ kraju dokumenta stoji da „Glas Koncila nije uložio žalbu” na rješenje suda.

Iz dnevničkih zabilješki biskupa Franje Kuharića doznajem i mnoge druge pojedinosti vezane uz taj slučaj. Kuharić s nadnevkom 19. veljače piše:

„Navečer u televizijskom dnevniku bio je javljeno da je odlukom javnog tužioštva zabranjeno raspačavanje ovog broja Glasa Koncila. Lijepo je pročitan naslov članka i podnaslov. Tako je i na televiziji spomenuta desetgodišnjica blažene smrti Nadbiskupa Stepinca. [...] Htjeli smo na svoj način pripremiti javnost i Partiju da se skine tabu s Nadbiskupa Stepinca i da se pomalo počimaju psihološki pripremati na njegovu rehabilitaciju. Prošli broj su podnijeli ali ovaj ne i to najviše radi citata njegove propovijedi od 30.X.1943. kojom je demantirana cijela njihova optužnica i osuda! Pitali smo se tko bi mogao od njih preuzeti odgovornost za taj korak, da li hrvatski CK ili žankovci! U tom sukobu svakako ne bismo htjeli dati povoda žankovcima da budu još agresivniji. Dakle, još uvijek se ostaje kod stanovišta osude! A ta nije bila ni kod nas ni u svijetu /samo u Partiji/ nikada priznata kao pravedna. Osuđen je nevini čovjek! Objektivna povijest još mora šutjeti!"78

Sutradan, 20. veljače, Kuhariću je došao Vladimir Bajsić, koji se u međuvremenu telefonski čuo s predsjednikom Komisije Zlatkom Fridom, te ga je upoznao sa sadržajem toga razgovora. Kuharić piše:

„Iz toga razgovora se može zaključiti kao sigurno da je hrvatski CK poduzeo tu mjeru protiv Glasa Koncila da ga ne bi unitaristi optuživali da više nema vlasti u Hrvatskoj. Frid je rekao: [...] Dopuštam da je Stepinac možda i nevin, ali to će moći priznati generacija iza nas. Mi smo previše uključeni u to zbivanje. Sada u ovoj situaciji bio bi veoma loše potezati rehabilitaciju Stepinca. To bi značilo srušiti ljude koji sada jedino mogu nešto učiniti i koji su ušli u vrlo težak spor. Situacija je unutra napeta. Pobjeda hrvatskog CK protiv unitarista još nije sigurna. To je bio prema Bajsićevom pripovijedanju sadržaj razgovora." ${ }^{79}$

\footnotetext{
${ }^{76}$ Riječ je o knjizi El proceso de monseñor Stepinac.

77 Arhiv Glasa Koncila, ur. br. 20/70, „Činjenični i pravni supstrat”, 6. 3. 1970., 5.

${ }^{78}$ HR-NAZ, Ostavština Franje Kuharića, Dnevničke zabilješke 1969-1973, korice 1, sveš. 1, 106-107.

${ }^{79}$ Isto, 108.
} 
Kuharić u svojem dnevniku piše da je Zlatko Frid i prije rasprave znao kakva će biti presuda. Naime, u razgovoru koji je 5. ožujka vodio s Tomislavom Šagi-Bunićem ovaj mu je prenio da je prije suđenja listu telefonski razgovarao s Fridom. „On je rekao kakva će biti i osuda: izrezivanje lista!”80

\section{Zabrana „Glasa Koncila” br. 21 od 22. listopada 1972.}

O zabrani raspačavanja Glasa Koncila br. 21 od 22. listopada 1972. list je sam izvijestio svoje čitatelje. ${ }^{81}$ Toga su puta, kako se kaže u toj obavijesti, kao razlog navedena čak tri članka: reportaža „Sedamnaest stoljeća svetog prkosa”, izvješće „Svečano primanje kod Nadbiskupa u povodu 10-te obljetnice Glasa Koncila” i pismo čitatelja „Katoličkih novina prije rata nije bilo”.

U rješenju o privremenoj zabrani raspačavanja Okružnoga javnog tužilaštva u Zagrebu (br. KTR-1201/72 od 20. listopada) kao inkriminacija se navodi da je list spornim člancima „pozvao građane na neposlušnost i nepoštivanje Ustava i Zakona SFRJ i SRH”, "glorificirao Alojzija Stepinca, političkog suradnika okupatora i fašističkog režima ustaške NDH” te iznosio „lažne tvrdnje o nepostojanju slobode štampe u našoj zemlji". ${ }^{22}$ Navedeni su i sporni dijelovi teksta:

1) iz reportaže „Sedamnaest stoljeća...”:

„Osobito je Polion tvrdio da ima zakona pravednih koje su kršćani dužni obdržavati, ali da ista vlast zna izdati odredbe koje nisu pravedne, zakone koje vjernik ne smije prihvatiti. [...] Kad se Polion pred istražiteljem i sucem Probom (u ono vrijeme tužilaštvo nije bilo odijeljeno od sudstva ni sudstvo od izvršne vlasti, pa je bilo 'kadija te tuži - kadija sudi') spomenuo zapovijedi vječnog Kralja, Prob se trgnuo, zainteresirao, žurno je zapitao kakav je to kralj koji mimo cara može u Carstvu zapovijedati. [...] Bog nezavisan od cara - to je mogući temelj svake revolucije. Kako bi carski službenici mogli mirno spavati, dok ima ljudi kojima carska i vladarska riječ nije posljednja, koji se usuđuju po svojoj savjesti ispitivati jesu li državni zakoni dobri ili zli, treba li im se pokoravati ili ih djelom i riječju osporavati?" 83

2) iz izvješća „Svečano primanje...”:

„[...] dr. Bajsić, kao pročelnik centra Kršćanska sadašnjost, predao je na ruke glavnog urednika GK malu brončanu statuu Kardinala Stepinca u znak priznanja za 10 godišnje djelovanje lista. Namjera je da ta statua postane znak najvećeg godišnjeg priznanja istaknutijim djelatnicima u Crkvi među Hrvatima." ${ }^{34}$

\footnotetext{
${ }^{80}$ Isto, 116.

${ }^{81}$ Usp. „Sudski zabranjeno raspačavanje Glasa Koncila Br. 21/72”, Glas Koncila, 5. 11. 1972., 2.

82 Arhiv Glasa Koncila, ur. br. 16/72, Rješenje OJT Zagreb br. KTR-1201/72, 20. 10. 1972.

83 Živko KUSTIĆ, „Sedamnaest stoljeća svetog prkosa”, Glas Koncila, 22. 11. 1972., 10-11.

${ }^{84}$ „Svečano primanje kod Nadbiskupa u povodu 20. obljetnice Glasa Koncila”, Glas Koncila, 22. 11. 1972., 7 .
} 
3) iz pisma „Katoličkih novina...”:

„I Glas Koncila je djelo sadašnjih prilika: djelo je ograničene slobode tiska, što više ograničeno u radu strahom [...]." 85

Raspravi koja je pred Vijećem Okružnoga suda u Zagrebu održana 23. listopada 1972. pristupili su Živko Kustić uime uredništva ${ }^{86}$ te, zanimljivo, upravo autor inkriminiranoga pisma čitatelja Zlatko Kuntarić, ali u svojstvu odvjetnika nakladnika, Nadbiskupskoga duhovnog stola. On je pritom rekao da je u prvom članku riječ o opisu povijesnih događaja, koji nemaju „nikakove veze [...] sa zakonima naše države”. ${ }^{87}$ Za drugi je članak rekao da je „dužnost svakih novina donijeti potpunu istinu o onome što se je dogodilo" ${ }^{88}$ a tužilaštvo ničime ne dokazuje da se opisani događaj nije dogodio. Što se pak tiče objavljenoga pisma, Kuntarić je tvrdio da ga tužilaštvo uopće nije „seriozno pročitalo”, jer se u njemu govori da „su ti članci koji nisu mogli biti objelodanjeni u Glasu Koncila radi ograničene slobode kao katoličkog lista, izašli na teritoriju naše države potpunoma slobodno i po neograničenoj slobodi”. ${ }^{9}$

Kustić je pročitao pisano obrazloženje - koje je predano u spis, pa ga zapisnik ne donosi - u kojem je poručio da bi tužilaštvo, ne bi li dokazalo svoje tvrdnje da Glas Koncila poziva na nepoštovanje Ustava i zakona SFRJ, najprije „trebalo [bi] dokazati tj. pokazati da zaista u SFRJ i SRH ima zakona kojima bi se vjernici po kršćanskoj savjesti trebali protiviti”, odnosno trebalo bi pokazati „da je Glas Koncila neke od postojećih zakona označio kao takve".90

Što se tiče članka u kojem se spominje Stepinac, Kustić je istaknuo da je Stepinac „kaznu izdržao, te se sada ne nalazi ni pod kaznom gubitka građanskih prava”. ${ }^{91}$ Osim toga riječ je o „priznavanju njegovih zasluga na područjima koja nemaju veze s onim djelima za koja ga je sud proglasio krivim". ${ }^{2}$ Dodao je i da Stepinac ima velikih zasluga za život Zagrebačke nadbiskupije te da ga i „građani Zagreba neprekidno štuju” kiteći cvijećem njegov grob i paleći svijeće, pa tužilaštvo nikada nije zbog toga pokušavalo „okriviti odgovorne crkvene ljude" ${ }^{93}$ Za treći je tekst i Kustić ustvrdio da se on uopće

\footnotetext{
${ }^{85}$ Zlatko KUNTARIĆ, „Katoličkih novina prije rata nije bilo”, Glas Koncila, 22. 11. 1972., 17.

${ }^{86}$ Dotadašnji je glavni urednik Glasa Koncila Vladimir Pavlinić odmah nakon pokretanja sudskoga postupka protiv lista napustio Hrvatsku i otputovao najprije u Beč, a potom se i odselio u London. Usp. MIKIĆ, „Crkveno i društveno značenje Glasa Koncila”, 41, bilj. 135.

${ }^{87}$ Arhiv Glasa Koncila, ur. br. 18/72, Zapisnik s Rasprave pred Okružnim sudom u Zagrebu br. Kr-33/72-3, 23. 10. 1972., 2.

88 Isto.

${ }^{89}$ Isto.

${ }^{90}$ Arhiv Glasa Koncila, ur. br. 19/72, „Živko Kustić, zamjenik gl. i odg. urednika Glasa Koncila na glavnoj raspravi..., 1.

91 Isto, 2.

92 Isto.

${ }^{93}$ Isto.
} 
ne odnosi na „neslobodu” građanskoga/svjetovnoga, nego „isključivo na određenu neslobodu crkvenoga tiska”, koji je „redovito podložan crkvenoj cenzuri s obzirom na ispravnost moralne i vjerske nauke". ${ }^{4}$

U završnoj riječi na raspravi 23. listopada predstavnik nakladnika zatražio je i da se Glas Koncila ne povezuje s Hrvatskim tjednikom, jer njegovo (Glasa Koncila) uredništvo nije imalo niti ima ikakvih političkih pretenzija, te da ga se ne dovodi u vezu s ekstremnom ili političkom emigracijom. ${ }^{95}$ Kako se povezivanje Glasa Koncila s Hrvatskim tjednikom i „ekstremnom emigracijom” ne navode ni u zapisniku ni u rješenju suda, nisam uspio ustanoviti što je tužilaštvo na raspravi u tom smislu točno tvrdilo. No, iz žalbe Nadbiskupskoga duhovnog stola Vrhovnom sudu Hrvatske u Zagrebu na rješenje Okružnoga suda, u kojem se poziva na „usmeno obrazloženje” tužilaštva, može se razaznati da je ono u tom usmenom obrazloženju iznijelo optužbu da je pisanje Glasa Koncila nastavak pisanja Hrvatskoga tjednika te da političkoj emigraciji "nakon zabrane Hrvatskog tjednika ostaje jedino Glas Koncila".96

Vrhovni je sud žalbu Nadbiskupskoga duhovnog stola odbio kao neosnovanu 8. studenog 1972. godine. ${ }^{97}$ Odvjetnik Zlatko Kuntarić uime nakladnika podnio je 23. studenog 1972. prijedlog Saveznom javnom tužilaštvu u Beogradu da uloži zahtjev za zaštitu zakonitosti protiv rješenja Okružnoga suda i rješenja Vrhovnoga suda Hrvatske. U tom se prijedlogu kaže da rješenja Okružnoga i Vrhovnoga suda „ograničuju prava, koja imade Rimokatolička vjerska zajednica na osnovu pozitivnih zakonskih propisa i ustavnih odredaba” te „u dijelovima inkriminiranih napisa nema nikakvih elemenata za primjenu čl. 52. Zakona o štampi i drugim oblicima informacija". ${ }^{98}$ No, Savezno je tužilaštvo taj predmet, pozivajući se na čl. 16., st. 1. i 2., toč. 31. Ustavnoga zakona za sprovođenje ustavnih amandmana XX do XLI ${ }^{99}$, ustupilo Javnom tužilaštvu SR Hrvatske ${ }^{100}$, koje ga je odbilo 31. siječnja 1973. godine. ${ }^{101}$

\section{Zabrana „Glasa Koncila” br. 7 od 1. travnja 1973.}

Glas Koncila br. 7 od 1. travnja 1973. najprije je rješenjem Okružnoga javnog tužilaštva (br. KTR-395/73 od 3. travnja 1973.) privremeno zabranjen, i to

\footnotetext{
${ }^{94}$ Isto.

${ }^{95}$ Usp. Arhiv Glasa Koncila, ur. br. 18/72, Zapisnik s Rasprave pred Okružnim sudom u Zagrebu br. Kr-33/72-3, 23. 10. 1972., 4.

${ }^{96}$ Arhiv Glasa Koncila, ur. br. 29/72, Žalba Nadbiskupskog duhovnog stola Vrhovnom sudu Hrvatske, 28. 10. 1972., 2.

${ }_{97}$ Usp. Arhiv Glasa Koncila, ur. br. 32/72, Rješenje Vrhovnoga suda Hrvatske br. I Kž 1730/723, 8. 11. 1972.

${ }^{98}$ Arhiv Glasa Koncila, ur. br. 36/72, Prijedlog Saveznom Javnom tužilaštvu, 23. 11. 1972., 1.

${ }^{99}$ Službeni list SFRJ, 29 (1971).

${ }^{100}$ Arhiv Glasa Koncila, ur. br. 40/72, Obavijest Saveznog javnog tužilaštva o ustupanju predmeta Javnom tužilaštvu SR Hrvatske Ktz. br. 938/1972, 5. 12. 1972.

${ }^{101}$ Arhiv Glasa Koncila, ur. br. 14/73, Dopis Javnog tužilaštva Hrvatske odvjetniku Zlatku Kuntariću br. Ut-221/72, 31. 1. 1973.
} 
zbog više „spornih” članaka. Po mišljenju tužilaštva, u člancima „Neočekivano ugrožen nastavak sporazumijevanja Svete stolice i vlade ČSSR” ${ }^{102}$, „Sveta stolica - ČSSR”, „Incident u Olomoucu 8. ožujka” i „Casaroli vjeruje jamstvima” 103 te u članku „Vjera u Sovjetskom savezu”104 list je prikazao „položaj Katoličke crkve i slobode vjeroispovijesti u socijalističkim istočno-evropskim zemljama na provokativan i tendenciozan način pokušavajući u javnosti stvoriti uvjerenje o neprikladnosti socijalističkog društvenog sistema za građane vjernike i o nužnosti njihovog okupljanja oko Katoličke crkve kao tobožnjeg jedinog zaštitnika njihovih vjerskih i nacionalnih interesa”. ${ }^{105}$ Osim toga u rješenju se procjenjuje da se u članku „Neobična suradnja Pavla VI i Komunističke partije Italije" 106 "tendenciozno piše o poruci koju je papa Pavle VI uputio sjeverno vijetnamskoj vladi posredstvom predstavnika KPI, optužujući KPI da je tu akciju Katoličke crkve prvenstveno iskoristila za svoje vlastite političke ciljeve”, čime list „neposredno remeti održavanje i razvijanje prijateljskih odnosa između Jugoslavije i drugih zemalja”. ${ }^{107}$ Inkriminirani su i članci „Kod Hrvata 'na kraju svijeta"'108 autora Živka Kustića, čija je svrha, prema donesenom rješenju, „da našoj javnosti lažno prikaže Katoličku crkvu kao jedinog stvarnog zaštitnika interesa hrvatskog naroda i da postojeći politički kurs u našoj zemlji na dosljednoj izgradnji demokratskog samoupravnog socijalističkog uređenja dovede u sumnji”, ${ }^{109}$ te tekst Tomislava Šagi-Bunića „Pravda mora pobijediti”, 110 u kojem se „tendenciozno i aludirajući na naše sadašnje političke prilike u kurzivu navode stihovi iz Bogovićevog 'Nevena' iz 1852. godine”."111

Nakon rasprave pred Okružnim sudom u Zagrebu, koja je održana 6. travnja 1973., sud donosi rješenje ${ }^{112}$ (br. KR-16/73-3) o zabrani raspačavanja i uništavanju tiskanih primjeraka i štamparskoga sloga, na što je nakladnik, Nadbiskupski duhovni stol, uložio žalbu Vrhovnom sudu Hrvatske. U njoj se, među ostalim, kaže da sporni članci vezani uz ČSSR „predstavljaju vijesti, koje su postale opća svojina, jer su sadržajno činjenice objelodanjene ne samo u katoličkom tisku nego u velikom dijelu evropske i svjetske štampe i prenose se u skoro svim svjetskim agencijama”"113, a sporni dio članka „Vjera u Sovjetskom

\footnotetext{
${ }^{102}$ Glas Koncila, 1. 4. 1973., 1.

${ }^{103}$ Isto, 4.

${ }^{104}$ Isto, 7.

${ }^{105}$ Arhiv Glasa Koncila, ur. br. 19/73, Rješenje OJT u Zagrebu br. KTR-395/73, 3. 4. 1973., 1. Citirani dio rješenja vidi i u: NOVAK, Hrvatsko novinarstvo u 20. stoljeću, 740.

106 Glas Koncila, 1. 4. 1973., 4.

107 Arhiv Glasa Koncila, ur. br. 19/73, Rješenje OJT u Zagrebu br. KTR-395/73, 3. 4. 1973., 1.

${ }^{108}$ Glas Koncila, 1. 4. 1973., 8-9.

109 Arhiv Glasa Koncila, ur. br. 19/73, Rješenje OJT u Zagrebu br. KTR-395/73, 3. 4. 1973., 1.

${ }^{110}$ Glas Koncila, 1. 4. 1973., 5-6.

111 Arhiv Glasa Koncila, ur. br. 19/73, Rješenje OJT u Zagrebu br. KTR-395/73, 3. 4. 1973., 2.

112 Zapisnik s rasprave i Rješenje br. KR-16/73-3, kao i KR-16/73-5, vidi u: Arhiv Glasa Koncila, ur. br. 18/73.

${ }^{113}$ Arhiv Glasa Koncila, ur. br. 18/73, Žalba Nadbiskupskog duhovnog stola Vrhovnom sudu Hrvatske protiv Rješenja Okružnog suda, 6. 4. 1973., 1.
} 
savezu” zapravo je „slobodna reprodukcija sovjetskog lista Pravda Ukrainy i s tim u vezi izvještaj moskovskog dopisnika milanskog Giorna". ${ }^{14}$

No, žalbu je Vrhovni sud odbio kao neosnovanu rješenjem od 7. svibnja 1973. godine. U njegovu obrazloženju stoji da „po shvaćanju ovoga suda list Glas Koncila predstavlja glasilo isključivo i izrazito vjerskog karaktera, te takva obilježja treba da imaju napisi, teme i problemi koji se u tom listu tretiraju. No i sam letimični pogled na stranice zabranjenog broja ovoga lista dokazuje, da on obiluje nizom članaka /i to ne samo onih koji su inkriminirani/, u kojima se tretiraju problemi prvenstveno političkog karaktera, dok pitanja vjerskog karaktera, kojima taj list treba da se bavi, imaju u tim člancima neznatan ili posve sporedan značaj". 15

\section{Zabrana „Glasa Koncila” br. 12 od 10. lipnja 1973.}

Sličan pravni put doživio je i br. 12 Glasa Koncila od 10. lipnja 1973., čije je raspačavanje - zbog članaka „Susret nade” i „Vapaj raspršenih katolika”"16 - najprije Okružno javno tužilaštvo 8. lipnja privremeno zabranilo (Rješenje br. KTR-679/73) s obrazloženjem da je list u njima „na tendenciozan i provokativan način prikazao stanje i rješavanje problema Katoličke crkve istočnog obreda u NR Rumuniji, prezentirajući ga čitaocima kao miješanje državne vlasti u poslove crkve". ${ }^{117}$ Potom je Okružni sud u Zagrebu, nakon provedene rasprave 12. lipnja, zabranio taj broj lista te oduzeo i uništio njegove primjerke (Rješenje br. KR 20/73), a žalbu Nadbiskupskoga duhovnog stola u Zagrebu Vrhovni sud Hrvatske odbio je kao neosnovanu 6. srpnja 1973. (Rješenje br. I KŽ 1314/1973-3). ${ }^{118}$

Za razliku od svih prijašnjih rješenja o zabrani raspačavanja, oduzimanju i uništavanju pojedinih brojeva lista (u slučaju br. 4/1970 samo spornoga članka), koja su donošena na temelju Zakona o štampi i drugim oblicima informacija, ovo je doneseno na temelju novoga Zakona o sprečavanju zloupotrebe štampe i drugih oblika informiranja od 19. travnja 1973. godine. ${ }^{119}$ Kako ističe Božidar Novak, taj je zakon donesen u sklopu pojačane represije nakon sloma hrvatskoga proljeća 1971., a cilj mu je bio „staviti medije i novinare pod strogu partijsku i državnu kontrolu" ${ }^{120}$ propisivanjem većega broja zabrana i kazni, uvođenjem obveze nakladnicima i tiskarima da odmah nakon tiskanja dostave primjerke listova i knjiga okružnom javnom tužitelju i sl.

${ }^{114}$ Isto, 2.

${ }^{115}$ Arhiv Glasa Koncila, ur. br. 21/73, Rješenje Vrhovnog suda br. I KŽ 777/1973-3, 7. 5. 1973., 2.

${ }^{116}$ U: Glas Koncila, 10. 6. 1973., 3.

117 Arhiv Glasa Koncila, ur. br. 23/73, Rješenje Okružnog suda u Zagrebu br. KR-20/73, 3. Tekst privremenoga rješenja Okružnoga javnog tužilaštva nije mi bio dostupan, pa ga citiram po navodima u obrazloženju Rješenja Okružnoga suda.

${ }_{118}$ Navedeno rješenje i žalbu vidi u: Arhiv Glasa Koncila, ur. br. 24/73.

119 Službeni list SFRJ, 22 (1973).

${ }^{120}$ NOVAK, Hrvatsko novinarstvo u 20. stoljeću, 747. 
U rješenju protiv toga broja Glasa Koncila sud se pozvao na čl. 2., st. 1., toč. 4. toga zakona, koji propisuje zabranu raspačavanja i zapljenu lista zbog remećenja održavanja prijateljskih odnosa s drugim narodima. ${ }^{121} \mathrm{U}$ obrazloženju se ističe da „ne može biti od koristi za socijalističku Jugoslaviju a posebno za njeno prijateljstvo s Rumunjskom ovakav natpis pa makar on u povijesnom pogledu i bio točan, iako što se tiče točnosti natpisa valja izraziti duboku sumnju da bi 6 biskupa utamničenih i u tamnicama umrli". ${ }^{122}$ Listu je zamjereno i to što je temu položaja katolika u Rumunjskoj tematizirao upravo u vrijeme „kad je član Predsjedništva SKJ i Izvršnog biroa drug Jure Bilić bio u prijateljskoj posjeti Komunističkoj partiji Rumunjske". ${ }^{123}$ Osim navedene inkriminacije listu se zamjera što u spornome članku implicira neprikladnost socijalističkoga društvenog uređenja te nužnost „okupljanja oko Katoličke crkve kao jedinog zaštitnika njihovih vjerskih i nacionalnih interesa” te što Glas Koncila „ima tendenciju da tretira probleme prvenstveno političkog karaktera dok pitanja vjerskog karaktera kojima bi taj list trebao da se bavi imaju sporedan značaj”." 24

\section{Kazneni postupak protiv Živka Kustića kao autora „Glasa Koncila”}

Osim protiv Glasa Koncila, 1972. pokrenut je, nekoliko mjeseci prije prethodno opisanih sudskih postupaka, i kazneni postupak protiv Živka Kustića $^{125}$ kao njegova autora, i to zbog reportaže iz Banata objavljene u veljači 1972. godine. ${ }^{126}$

Kustić se u tom tekstu uvodno referirao na dokument Sinode o biskupima u kojem se ističe „kako svaki narod u duhu Evanđelja ima pravo na samosvojnost, na svoju nacionalnu izvornost na svim područjima duhovne i materijalne kulture, u trenutku kad je zagrebački nadbiskup pred Božić 1971. naglasio kako je Isus Krist, utjelovivši se, postao članom jednoga određenog naroda i time posvetio rodoljublje ${ }^{127}$, Sveta Stolica odlučila je udovoljiti davnu težnju madžarskih katolika u Banatu te im je imenovala biskupa madžarske krvi i jezika”. Nakon toga Kustić je primijetio da bi trebalo osigurati

${ }^{121}$ Usp. Arhiv Glasa Koncila, ur. br. 24/73, Rješenje Okružnog suda br. KR-20/73, 12. 6. 1973., 3.

${ }^{122}$ Isto, 5.

${ }^{123}$ Isto, 6.

${ }^{124}$ Isto.

125 Taj je sudski postupak opisan i u: HUDELIST, Rim, a ne Beograd, 202-224. No, u ovom se radu ne oslanjam na tu knjigu, nego na izvorne sudske spise, a autoru dugujem prije svega informaciju o postojanju i mjestu pohrane toga sudskog spisa.

${ }^{126}$ Usp. Ž. K. [Živko Kustić], „Između Tise i Dunava. (U povodu imenovanja prvog Madžara biskupom u SFRJ)”, Glas Koncila, 6. 2. 1972., 10-11.

${ }^{127}$ Usp. „Božićna poruka nadbiskupa Franje Kuharića. Isus Krist posvetio je rodoljublje”, Glas Koncila, Božić 1971. Taj je članak, uz nekoliko drugih, bio povodom da ,je bilo razmišljanja o eventualnoj zabrani raspačavanja" toga broja, kako su tadašnjem glavnom uredniku lista Vladimiru Pavliniću na sastanku 20. prosinca 1971. priopćili službenici Komisije Ivan Ceranić i Vitomir Unković. U: HR-HDA-310-KOVZ, kut. 92, Pov. br. 114/1971, Zabilješka o razgovoru s Vladimirom Pavlinićem, 2. 
„mnogo više svećenika za službe hrvatskim i slovenskim katolicima po srbijanskim gradovima i gradićima. A za te se iseljenike ne brine čak ni vlč. Vladimir Stanković; uopće Crkva u Hrvatskoj i Sloveniji malo ili nimalo ne misli da je beogradski nadbiskup pastir njenih odseljenih ovaca". ${ }^{128}$

Najprije je na dan tiskanja „spornoga” teksta u Glasu Koncila Općinsko javno tužilaštvo I. Zagreb 4. veljače 1972. uputilo Općinskom sudu u Zagrebu, odnosno istražnom sucu, zahtjev za pokretanje „istražne radnje ispitivanjem osumnjičenog” (br. KT-5137/72, veza Kir 129/72-1), ${ }^{129}$ i to zbog sumnje u počinjenje kaznenoga djela „Širenja lažnih vijesti” iz toč. 292a KZa. ${ }^{130}$ No, Općinski sud Rješenjem br. 5 Kir-129/72-6 od 11. veljače proglašava se nenadležnim na temelju čl. 35., st. 1. Zakona o krivičnom postupku, a u vezi s čl. 130. Zakona o štampi, te zahtjev ustupa Okružnom sudu u Zagrebu. Ispitivanje Živka Kustića pred okružnim sucem obavljeno je 27. ožujka (Zapisnik Okružnog suda o ispitivanju br. Kir-129/72-9).

Potom Okružno javno tužilaštvo Okružnom sudu u Zagrebu 12. travnja 1972. podnosi novi zahtjev za provođenje istrage protiv Živka Kustića (br. KT-259/72, veza Kio 471/72), no toga puta Kustića se teretilo za još ozbiljnije kazneno djelo „Neprijateljske propagande”, opisano u čl. 118., st. 1. KZ-a ${ }^{131}$, pa 17. travnja Okružni sud izdaje i naredbu o pretrazi Kustićeva stana (br. Kio 471/72-2). Kustića je istražni sudac ponovno ispitao 17. kolovoza (Zapisnik Okružnog suda br. Kio-471/72-4).

$\mathrm{Na}$ ispitivanjima 27. ožujka i 17. kolovoza 1972. istražnoga je suca osobito zanimalo što je Kustić mislio pod pojmom „odseljenih” i zašto u tekstu spominje vlč. Stankovića, koji se brine za „inozemnu pastvu”. Kustić se branio objašnjenjem da je pod „iseljenicima” mislio isključivo na seljenje vjernika iz jednoga u drugo crkveno-administrativno područje te se ni na koji način nije bavio granicama u nekom drugom smislu, a za Stankovića je objašnjavao da se on ne brine samo za vjernike izvan SFRJ, nego se kao član Vijeća Biskupske konferencije za migraciju brine i o vjernicima koji su se

${ }_{128}$ Ž. K. [Živko Kustić], „Između Tise i Dunava...”, Glas Koncila, 6. 2. 1972., 10.

${ }^{129}$ Sve sudske dokumente vezane uz proces Živku Kustiću, ako izričito ne navedem drukčije, citirat ću iz obimne dokumentacije sadržane u sudskom spisu pohranjenom u Državnom arhivu u Zagrebu, navodeći ih po izvornoj signaturi. Usp. HR-DAZG-1007, Spis br. K-2/1973.

${ }_{130}$ Službeni list FNRJ, 30 (1959), „Zakon o izmjenama i dopunama Krivičnog zakonika”, čl. 213.: „Čl. 292a. Tko iznosi ili pronosi lažne vijesti ili tvrdnje u namjeri da izazove neraspoloženje ili uznemirenje građana ili da se ugrozi javni red ili mir, ili to učini u namjeri da se osujeti sprovođenje javnih odluka i mjera državnih organa i ustanova ili da se umanji povjerenje građana u takve odluke i mjere, kaznit će se novčanom kaznom ili zatvorom do jedne godine."

${ }_{131}$ Službeni list FNRJ, 30 (1959), „Zakon o izmjenama i dopunama Krivičnog zakonika”, čl. $60 .:$ „Čl. 118, st. 1. Tko napisom, govorom ili na drugi način poziva ili podstiče na nasilnu ili protuustavnu promjenu društvenog ili državnog uređenja, na svrgavanje predstavničkih tijela ili njihovih izvršnih organa, na razbijanje bratstva i jedinstva naroda Jugoslavije ili na otpor prema odlukama predstavničkih tijela ili njihovih izvršnih organa koje su od značaja za zaštitu i razvitak socijalističkih društvenih odnosa, bezbjednost ili obranu zemlje, ili tko zlonamjerno ili neistinito prikazuje društveno-političke prilike u zemlji, kaznit će se strogim zatvorom do 12 godina." 
preselili unutar same SFRJ. Na drugom je ispitivanju izrazio čuđenje „promjenom kvalifikacije" djela za koje se tereti - od čl. 292a na čl. 118., st. 1. $\mathrm{KZ}$-a - premda je riječ o jednom te istom njegovu tekstu.

Rješenje o provođenju istrage protiv Kustića zbog sumnje u kazneno djelo iz čl. 118., st. 1. KZ-a Okružni sud donosi 21. rujna 1972. (br. Kio-471/726), a istoga dana od Biskupske konferencije dopisom traži objašnjenje „funkcije, dužnosti i razgraničenja između Ravnateljstva za Hrvatsku inozemnu pastvu i Vijeća Biskupske konferencije za Hrvatsku migraciju", kao i dužnosti vlč. Vladimira Stankovića u tim tijelima (br. Kio-471/72-5). Biskupska konferencija odgovara im dopisom od 28. rujna (br. 516/BK-1972), u kojem tajnik Nikola Soldo objašnjava da je vlč. Stanković i tajnik Vijeća Biskupske konferencije za hrvatsku migraciju, u čiju je djelatnost „uključena briga za hrvatske vjernike katolike koji mijenjaju boravište u domovini ili izvan domovine". 132

Nakon što je Okružni sud 23. listopada 1972. donio odluku o zabrani raspačavanja Glasa Koncila br. 21/1972, o čemu je bilo riječi prije, Okružno javno tužilaštvo 24. listopada traži proširenje istrage (br. KT 259/72, veza Kio 471/72) protiv Kustića kao autora reportaže „Sedamnaest stoljeća svetog prkosa" ${ }^{133}$, koja je bila i jedan od inkriminiranih članaka zabranjenoga broja. Okružni sud tom zahtjevu tužilaštva udovoljava rješenjem od 25. listopada (br. Kio-1246/72-3). Dakako, u svim dotadašnjim stadijima istrage obrana Živka Kustića podnosila je brojne prigovore, ali svi su bili odbijeni. ${ }^{134}$ Istražni sudac Kustića ponovno ispituje 30. listopada (Zapisnik br. Kio-1216/72-2), a o tom ispitivanju i cijelom sudskom procesu toga je puta obavijest javnosti dao sam Glas Koncila, javljajući da je "na zahtjev javnog tužilaštva istražni sudac Vladimir Marković pozvao [je] pisca reportaže 'Sedamnaest stoljeća svetoga prkosa', Živka Kustića, na ispitivanje kao okrivljenog po čl. 118/1 Kaznenog zakonika. Istraga je u toku”."135

Napokon 23. studenog 1972. Okružno javno tužilaštvo podnosi Okružnom sudu i optužnicu (br. KT-259/72), no ne po čl. 118., st. 1., nego za mnogo blaže kazneno djelo iz prije spominjanog čl. 292a. U optužnici se Kustića tereti da je reportažom „Između Tise i Dunava” „[...] Hrvate i Slovence koji prebivaju na teritoriju SR Srbije nazvavši ih iseljenicima izjednačio sa našim građanima koji žive u inostranstvu [...] u namjeri da kod Hrvatskog i Slovenskog naroda stvori uvjerenje da se boraveći u drugim republikama SFRJ nalazi u položaju naših građana u inostranstvu i stvarajući time kod njih osjećaj

\footnotetext{
${ }^{132}$ HR-DAZG-1007, Spis br. K-2/1973, Dopis Tajništva Biskupske konferencije Jugoslavije Okružnom sudu u Zagrebu, 28. 9. 1972.

${ }^{133}$ Živko KUSTIĆ, „Sedamnaest stoljeća svetog prkosa”, Glas Koncila, 22. 10. 1972., 1, 10-12.

${ }^{134}$ Usp. primjerice: Arhiv Glasa Koncila, ur. br. 33/72, Rješenje Okružnog suda o odbijanju žalbe br. Kv 1136/72-2 (Veza br. Kio 1246/72), 6. 11. 1972.

135 „Sudski zabranjeno raspačavanje Glasa Koncila Br. 21/72”, Glas Koncila, 5. 11. 1972., 2.
} 
neravnopravnog položaja u odnosu na građane republike u kojoj borave”, 136 a reportažom „Sedamnaest stoljeća svetog prkosa” „poziva građane vjernike na nepoštivanje pozitivnih propisa SRH i SFRJ, koristeći se pri tome opisom povijesnog događaja Katoličke crkve". ${ }^{137}$

No, Vijeće Okružnoga suda pod predsjedanjem suca Vojka Madirazze donijelo je 10. svibnja 1973. oslobađajuću presudu (br. K-2/73-9) uvažavajući dokaze - spomenuti dopis Biskupske konferencije i priložene dokumente o ustroju Vijeća Biskupske konferencije za migrante - da vlč. Stanković ne skrbi samo za vjernike iseljene izvan SFRJ nego i za migrante unutar SFRJ te da se spominjanje „iseljenika” u inkriminiranom članku ne može sa sigurnošću shvatiti kao njihovo izjednačavanje s građanima izvan SFRJ. Što se pak tiče drugoga članka, u obrazloženju presude sud ističe da „i pored činjenice da je članak pisan u vrijeme kada je u našem društvu vladala posebna društvena klima [...] još se uvijek ne može, po ocjeni ovoga suda, sa sigurnošću izvesti zaključak da je optuženi inkriminiranim člankom pozivao građane vjernike na nepoštivanje Ustava i zakona"138 jer, kako se objašnjava u nastavku, izvedeni dokazi ne upućuju na „nedvosmislenost aluzija za koje je optužen Kustić Živko, pa se stoga i ne može pouzdano zaključivati o njegovoj eventualnoj prikrivenoj namjeri”. ${ }^{139}$

Okružno javno tužilaštvo na tu se presudu 6. kolovoza 1973. žalilo Vrhovnom sudu (KT-259/72; K-2/73-12), a Vrhovni sud djelomično je uvažio žalbu, i to u odnosu na članak „Sedamnaest stoljeća svetog prkosa”, te je presudom od 20. kolovoza 1974. (Kž 1932/1973-3) Živka Kustića osudio na kaznu zatvora od pet mjeseci, uvjetno na dvije godine, uz zabranu istupanja u javnom tisku u trajanju od jedne godine.

Dokumenti iz Hrvatskoga državnog arhiva dodatno rasvjetljavaju taj sudski slučaj. Naime, iz Promemorije Komisije za vjerska pitanja od 29. ožujka 1973. proizlazi da je postupak pokrenut upravo na njihov zahtjev: „Naša je Komisija još početkom mjeseca veljače prošle godine dala prijedlog Okružnom javnom tužilaštvu u Zagrebu za pokretanje krivičnog postupka protiv novinara Glasa Koncila Živka Kustića”, stoji u Promemoriji te se dodaje da je tužilaštvo „prihvatilo naš prijedlog i pokrenulo postupak, te je nakon konzultacija s našom Komisijom podignuta i optužnica kod Okružnog suda u Zagrebu”. ${ }^{140} \mathrm{U}$ istom dokumentu njegovu se primatelju sugerira „da bi kod Okružnog suda u Zagrebu trebalo intervenirati da prestane s odugovlačenjem i da održi suđenje, jer nam je ovakva situacija već znatno štetila i otupljuje napore na onemogućavanju zloupotrebe vjernika u političke svrhe". ${ }^{141}$ Istodobno se objašnjavaju i

\footnotetext{
${ }^{136}$ HR-DAZG-1007, Spis br. K-2/1973, Optužnica Okružnog javnog tužilaštva protiv Živka Kustića br. KT-259/72, 23. 11. 1972., 1.

${ }^{137}$ Isto, 2.

${ }^{138}$ HR-DAZG-1007, Spis br. K-2/1973, Presuda Okružnog suda br. K-2/73-9, 10. 5. 1973., 5.

${ }^{139}$ Isto, 8.

${ }^{140}$ HR-HDA-310-KOVZ, kut. 100, Pov. br. 57, „Promemorija: Odugovlačenje suđenja novinaru Glasa Koncila", 29. 3. 1973.

${ }^{141}$ Isto.
} 
(politički) motivi zbog kojih je Komisija dala prijedlog za pokretanje sudskoga postupka:

„S obzirom da upravo Živko Kustić konstantno daje negativan ton Glasu Koncila kako u pogledu odabiranja tema tako i u njihovoj interpretaciji, čime se taj list konstantno predstavlja kao političko sredstvo konzervativnih i reakcionarnih snaga u Crkvi, pa i izvan nje, naša je Komisija već desetak puta intervenirala da Kustić konačno bude izveden pred sud [...].” ${ }^{142}$

Na samoj Promemoriji nije naveden izvorni primatelj, ${ }^{143}$ no iz pristigloga odgovora, ${ }^{144}$ koji je 10. svibnja 1973. poslao Republički sekretarijat za pravosuđe i opću upravu, zaključujem da je ona bila upućena upravo toj instituciji. Sekretarijat pritom obavještava Komisiju da se na njihovu promemoriju od 8. svibnja očitovalo Predsjedništvo Okružnoga suda u Zagrebu dopisom Pov. br. 8-73, u kojem je objasnilo da sudac koji vodi postupak protiv Kustića raspravu nije sazvao iz opravdanih razloga, odnosno zbog prije dogovorenih rasprava u drugim sudskim predmetima.

I u dnevniku nadbiskupa Kuharića nalazim njegovo svjedočanstvo o tome da je tih dana čuo za jednu znakovitu izjavu predsjednika hrvatske Komisije za vjerska pitanja Zlatka Frida. Naime, s nadnevkom 12. lipnja 1972. Kuharić piše da ga je posjetio fra Bernard Dukić, hrvatski svećenik koji je djelovao u Frankfurtu, te ga izvijestio o Fridovoj posjeti: „Dakako, Frid je izražavao nezadovoljstvo sa mnom [Kuharićem]. Rekao je da Kustića ni Bog neće spasiti od dugoga zatvora..." 145

Svoj susret s Fridom od 19. lipnja iste godine Kuharić je iskoristio da bi ga pitao je li to istina, ne iznoseći od koga je to čuo, te opisuje:

„Zanijekao je to. (Imam svjedoka da je to rekao u Njemačkoj). Rekao je da je Kustić napisao stvari koje izazivaju. Ima žalac. Napominje da je rekao tim ljudima da se sada pazi na svaku riječ pa neka budu oprezni. 'Po magli se vozi sa spuštenim svjetlom!' Rekao sam mu da se onda ne može govoriti o slobodi ako se mora biti u strahu za svaku riječ. Na to je on odgovorio: "Živimo u neslobodnom društvu i zato nema slobode!"'146

\footnotetext{
${ }^{142}$ Isto.

${ }^{143}$ Iz dopisa Pov. br. 08-57/1-1973. od 29. 3. 1973. vidljivo je da je Promemorija dostavljena i potpredsjedniku Izvršnoga vijeća Sabora SR Hrvatske Milanu Rukavini Šainu s „molbom za intervenciju", no on pritom nije naveden kao prvotni primatelj. U: HR-HDA-310-KOVZ, kut. 100, Pov. br. 57.

${ }^{144}$ HR-HDA-310-KOVZ, kut. 100, Pov. br. 57, Odgovor Republičkog sekretarijata za pravosuđe i opću upravu Komisiji, Pov. br. 40/1973-3, 10. 5. 1973. (na sam dan donošenja oslobađajuće presude Kustiću!, op. A. M.).

${ }^{145}$ HR-NAZ, Ostavština Franje Kuharića, Dnevničke zabilješke 1969-1973, korice 1, sveš. 3, Dnevnički zapis Franje Kuharića od 12. 6. 1972., 51.

${ }^{146}$ Isto, Dnevnički zapis Franje Kuharića od 19. 6. 1972., 55.
} 


\section{Zaključak}

U razdoblju obrađenom u ovome radu komunističke su vlasti u Hrvatskoj, i izvršne i sudske, provodile različite represivne mjere protiv katoličkih medija, njihovih nakladnika i istaknutih autora, uključujući i sudske postupke: od prekršajnih prijava i kazni nakladniku (Mali koncil) i odgovornim urednicima (Franjo Kuharić i Ivon Ćuk), preko sudskih zapljena i zabrane raspačavanja pojedinih brojeva listova ili pojedinih članaka u njima (Glasniksv. Antuna Padovanskoga i Glas Koncila), pa sve do kaznenoga progona urednika i istaknutih autora katoličkih listova toga vremena (Ivon Ćuk i Živko Kustić). Vlastima su pritom osobito smetali članci u katoličkom tisku koji su kritizirali nedostatak vjerskih sloboda u socijalističkim zemljama, promovirali humanitarno djelovanje Katoličke crkve, isticali fotografije hrvatskih nacionalnih simbola (zastava) bez socijalističkih obilježja, iznosili aluzije na položaj Hrvata u drugim republikama u Jugoslaviji te njegovali uspomenu na kardinala Alojzija Stepinca.

Za razliku od sudskih postupaka drugim, ne-crkvenim izdanjima i autorima, u onima protiv crkvenih tiskovina, njihovih nakladnika, urednika i autora korištena je i šira pravna osnova. Naime, osim Zakona o izdavačkim poduzećima i izdavačkim ustanovama, Zakona o štampi i drugim oblicima informacija, Zakona o sprečavanju zloupotrebe slobode štampe i drugih oblika informiranja te čl. 118/1 i 292a Krivičnoga zakonika - koji su bili uobičajena pravna osnova za sudske postupke protiv drugih tiskovina i autora toga vremena ${ }^{147}-\mathrm{u}$ slučaju crkvenih izdanja u sudskim su postupcima kao pravna osnova navođeni i članak Ustava koji je govorio o odvojenosti vjerskih zajednica i države te o protuustavnosti zloupotrebe vjere i vjerske djelatnosti u političke svrhe (čl. 46.), kao i čl. 311. KZ-a, koji je tu zloupotrebu zakonski sankcionirao. Pozivanje na te ustavne i zakonske odredbe, kao i na Zakon o pravnom položaju vjerskih zajednica, moglo bi se protumačiti kao dio nastojanja tadašnjih vlasti da se vjerski listovi prestanu baviti svakom drugom tematikom osim vjerske, a osobito da prestanu obrađivati politička i društvena pitanja.

I analiza arhivskoga gradiva korištenog i obrađenog u ovom radu jasno upozorava i na političku dimenziju i motivaciju tih procesa: od činjenice da su sudske mjere razmatrane, koordinirane i planirane u sklopu jednoga izvršnog tijela javne vlasti (Komisija za vjerska pitanja Izvršnoga vijeća Sabora SR Hrvatske), pa i na sastancima na kojima su, u duhu tadašnjega shvaćanja jedinstva vlasti, zajednički sudjelovali predstavnici političkih tijela (Saveza komunista i Socijalističkoga saveza), izvršne vlasti (Komisije), Javnoga tužilaštva i (predsjednika) pojedinih sudova, preko dokumentirane suradnje izvršne vlasti (Komisija) i Javnoga tužilaštva u pokretanju pojedinih sudskih postupaka, pa sve do otvorenoga pokušaja utjecanja Komisije na jedan sud (Okružni sud u Zagrebu) da bi se jedan konkretni kazneni sudski postupak (Živku Kustiću) ubrzao, uz jasno navođenje političkih motiva u samom zahtjevu. A sve to radi

${ }^{147}$ Usp. GRBELJA, Cenzura u hrvatskom novinstvu. 
utjecaja na uređivačku politiku katoličkih medija i prisilnoga ograničavanja njihova interesa i sadržaja na isključivo vjersku tematiku, kao i onemogućavanja Katoličke crkve da preko tih listova sudjeluje u životu društva i utječe na formiranje (političkih) stavova svoje publike.

Analizom obrađenih presuda moglo bi se zaključiti i da su sudski postupci kulminirali nakon sloma hrvatskoga proljeća 1971., u sklopu pojačane represije koja je u to vrijeme i inače zabilježena u Hrvatskoj, premda je sudskih postupaka bilo i od 1967. do 1971. godine. No, za razliku od nekih sudionika hrvatskoga proljeća, među kojima je bilo i autora u dijelu tadašnjega tiska, nijedna pravomoćna sudska presuda protiv autora u katoličkom tisku nije bila okončana bezuvjetnom zatvorskom kaznom premda su tadašnje Okružno javno tužilaštvo i predsjednik Komisije u više navrata tražili upravo takve kazne. To nas pak navodi na zaključak o blažem pristupu koji su sudovi imali prema katoličkim autorima i novinama od predstavnika tzv. organa gonjenja i izvršne vlasti. Tomu, primjerice, svjedoči izricanje blaže vrste kazne (ukora) suca za prekršaje Malom koncilu i njegovu uredniku Franji Kuhariću, a osobito prvostupanjska oslobađajuća presuda Živku Kustiću na Okružnom sudu u Zagrebu (unatoč prethodnoj intervenciji predsjednika Komisije prema sudu i povijesnom kontekstu pojačane represije nakon sloma hrvatskoga proljeća).

Da su u Komisiji za vjerska pitanja bili nezadovoljni takvim ishodom, odnosno činjenicom da sve poduzete mjere nisu uspjele postići da se katolički listovi, osobito Glas Koncila, prestanu baviti političkim i društvenim pitanjima, svjedoči i dopis koji je Komisija 1973. dostavila najvišim državnim i partijskim organima: Izvršnom vijeću Sabora, Saboru SR Hrvatske, CK SKH, odnosno njegovu izvršnom sekretaru Josipu (Joži) Vrhovcu, Republičkoj konferenciji SSRNH i Saveznom sekretarijatu za vanjske poslove. Naime, u dokumentu pod nazivom „Informacija o pisanju katoličkih novina Glasa Koncila, posebno posljednjeg, sedmog broja od 1. travnja 1973." (sudska zabrana toga broja obrađena je u ovome radu) Komisija rezignirano zaključuje:

„Ovdje je umjesno konstatirati da su ranija nastojanja da se pojedincima u Katoličkoj crkvi ukaže na neprihvatljivo pisanje Glasa koncila ostala bez rezultata. Nije djelovala ni zabrana tih novina, kao ni političke ocjene date od strane najviših partijskih i državnih funkcionera, kao ni izravne i oštre kritike upućene u više navrata zagrebačkom nadbiskupu. Radi toga, a zbog onemogućavanja daljnjeg političkog djelovanja kroz ove novine, kao jedino valjano sredstvo nameće se potreba zabrane daljnjeg izlaženja Glasa koncila." ${ }^{148}$

Tražena se zabrana nije dogodila, a sve do sredine osamdesetih godina nije bilo ni novih sudskih postupaka protiv katoličkoga tiska.

${ }^{148}$ HR-HDA-310-KOVZ, kut. 100, Pov. br. 58/1973, „Informacija o pisanju katoličkih dvotjednih novina Glasa Koncila, posebno posljednjeg, sedmog broja od 1. travnja 1973., 2. 4. 1973., 4. 


\section{Arhivsko gradivo}

Arhiv Glasa Koncila, Hrvatska, Zagreb.

HR-DAZG-1007: Hrvatska, Državni arhiv u Zagrebu, Zagreb, fond 1007, Okružni sud u Zagrebu.

HR-HDA-310-KOVZ: Hrvatska, Hrvatski državni arhiv, Zagreb, fond 310, Komisija za vjerska pitanja Izvršnog vijeća SR Hrvatske.

HR-NAZ: Hrvatska, Nadbiskupijski arhiv u Zagrebu, Zagreb:

- Prezidijal Šeper.

- Ostavština Franje Kuharića.

\section{Objavljeni izvori i tisak}

Glas Koncila (Zagreb), 1967, 1970-1973.

Službeni list FNRJ (Beograd), 13 (1951), 46 (1951), 22 (1953), 30 (1959), 44 (1959), 45 (1960).

Službeni list SFRJ (Beograd), 14 (1963), 29 (1971), 22 (1973).

\section{Literatura}

AKMADŽA, Miroslav. Katolička crkva u komunističkoj Hrvatskoj 1945. 1980. Zagreb; Slavonski Brod: Despot Infinitus, 2013.

ANCIĆ, Zvonimir. „Pregovori i ponovna uspostava diplomatskih odnosa između Vatikana i SFRJ”. Magistarski rad, Sveučilište u Zagrebu, 2012.

CAVALLI, Fiorello. El proceso de monseñor Stepinac. Madrid: Acción Católica Española - Ediciones Católicas, 1947.

GRBELJA, Josip. Cenzura u hrvatskom novinstvu 1945. - 1990. Zagreb: Naklada Jurčić, 1998.

HUDELIST, Darko. Rim, a ne Beograd. Promjena doba i mirna ofenziva Katoličke Crkve u Hrvatskoj u Titovoj Jugoslaviji (1975. - 1984.). Zagreb: Alfa, 2017.

MATAUŠIĆ, Juraj Mirko. „Katolički tisak u Zagrebačkoj nadbiskupiji”. U: Zagrebačka biskupija i Zagreb 1094 - 1994. Zbornik u čast kardinala Franje Kuharića, ur. Antun Škvorčević. Zagreb: Zagrebačka nadbiskupija; Katolički bogoslovni fakultet, 1995, 649-660.

MATAUŠIĆ, Juraj Mirko. „Prihvat Drugog vatikanskog koncila u Hrvatskoj na primjeru katoličkog tiska i odnosa Crkve prema medijima”. Časopis za suvremenu povijest 38 (2006), br. 2: 499-521.

MIHALJEVIĆ, Josip. „Liberalizacija i razvoj medija u komunističkoj Hrvatskoj 1960-ih i na početku 1970-ih". Društvena istraživanja 24 (2015), br. 2: 239-258.

MIKIĆ, Anto. „Crkveno i društveno značenje Glasa Koncila od 1963. do 1972.. Doktorska disertacija, Sveučilište u Zagrebu, 2016. 
MIKLENIĆ, Ivan. Pogledi u Glas Koncila. Zagreb: Glas Koncila, 2013.

NOVAK, Božidar. Hrvatsko novinarstvo u 20. stoljeću. Zagreb: Golden marketing - Tehnička knjiga et al., 2005.

PAVLINIĆ, Vladimir. „Katolička štampa u Hrvatskoj”. U: Mi Crkva i drugo. Zbornik Bogoslovske tribine. Zagreb: Kršćanska sadašnjost, 1971, 63-78.

PENAVA, Šimun. „Žrtve poratne represije: dvanaestorica pravednika”. U: Hrvatska provincija sv. Jeronima franjevaca konventualaca. Posljednjih stotinu godina (1907. - 2007.). Drugi svezak. Radovi znanstvenog skupa održanog u Zagrebu 29. i 30. rujna 2008. Zagreb: Hrvatska provincija sv. Jeronima franjevaca konventualaca; Veritas, 2009, 149-162.

RADELIĆ, Zdenko. Hrvatska u Jugoslaviji 1945. - 1991. Od zajedništva do razlaza. Zagreb: Hrvatski institut za povijest; Školska knjiga, 2006.

ROŠČIĆ, Nikola Mate. „O. Ivon Ćuk (1923. - 1983.). Život i djelo: Zanosni poslužitelj Riječi”. U: Hrvatska provincija sv. Jeronima franjevaca konventualaca. Posljednjih stotinu godina (1907. - 2007.). Drugi svezak. Radovi znanstvenog skupa održanog u Zagrebu 29. i 30. rujna 2008. Zagreb: Hrvatska provincija sv. Jeronima franjevaca konventualaca; Veritas, 2009, 591-600. 


\section{SUMMARY}

\section{Court Proceedings against the Catholic Press in Communist Croa- tia during the 1960s and 1970s}

This paper examines and presents court proceedings against the Catholic newspapers Mali koncil (Little Council), Glas Koncila (Voice of the Council), and Glasnik sv. Antuna Padovanskog (St Anthony of Padua's Herald), later the Veritas, and their editors and authors Franjo Kuharić, Živko Kustić, and Ivon Cuk during the 1960s and 1970s. Based on original archival material and relevant literature, seven court proceedings against Ivon Ćuk and Živko Kustić have been reconstructed. These include misdemeanour proceedings, the confiscation of or bans on the distribution of individual articles or issues of the mentioned papers, and two criminal proceedings, through which the communist authorities tried to limit the writing of the Catholic press and, indirectly, the activity of the Catholic Church in contemporaneous society. Using various research methods - analysis of contemporaneous legislation and court recor$\mathrm{ds}$, the contents of official correspondence between the then state and Church representatives, and individual articles published in the Catholic press - the author sheds further light on not only the legal aspects of these proceedings, but also their political background and motivation, placing them within the context of the contemporaneous relations between Church and state. The activities of the then Commission for Religious Matters of the Executive Committee of the Parliament of the Socialist Republic of Croatia regarding monitoring the contents of the Catholic press, resolving certain legal and political dilemmas related to initiating court proceedings, and its cooperation with the contemporaneous so-called "prosecution organs", especially the District Public Prosecutor's Office in Zagreb, are studied separately. Presenting certain reactions of Church representatives, especially through the diary entries of then Zagreb (arch)bishop Franjo Kuharić, the author has shown the way in which the mentioned court proceedings were experienced and "read" by the contemporaneous Church leadership in Croatia. It can be concluded that the then Catholic press - despite being faced with court proceedings - primarily fought for the freedom of the Catholic Church in contemporaneous society. However, in doing so the Catholic media and authors also indirectly broadened the freedom of the press and public speech in the Socialist Republic of Croatia and the Socialist Federal Republic of Yugoslavia, especially after 1971, when the Catholic Church remained the sole organised "opposition" force to the country's regime.

Key words: Catholic press under communist rule; Glas Koncila; Mali koncil; Veritas; Ivon Ćuk; Živko Kustić; Franjo Kuharić 